\title{
A Process of Denial: Bork and Post-Modern Conservatism
}

\author{
James Boyle*
}

[I]t is naive to suppose that the [Supreme] Court's present difficulties could be cured by appointing Justices determined to give the Constitution "its true meaning," to work at "finding the law" instead of reforming society. The possibility implied by these comforting phrases does not exist. . . . History can be of considerable help, but it tells us much too little about the specific intentions of the men who framed, adopted and ratified the great clauses. The record is incomplete, the men involved often had vague or even conflicting intentions, and no one foresaw, or could have foreseen, the disputes that changing social conditions and outlooks would bring before the Court.

Robert Bork ${ }^{1}$

\section{INTRODUCTION}

As you might guess from the title, Robert Bork's latest work, The Tempting of America, ${ }^{2}$ is a book about the Fall - both America's and Mr. Bork's own. It will not surprise many readers to find that the two are linked, or that the "temptation" to which Mr. Bork refers is that of politics. In particular, he warns us of an increasing politicization of the American legal system. This politicization is caused primarily by judges who desert the original understanding of the Constitution and, under the guise of "interpretation," attempt instead to impose their own individual notions of justice on the cases before them. Mr. Bork conveys these messages in a book which is part autobiography and part legal theory, inspired by the ordeal which brought him to fame: the Senate's judicial confirmation process. In his case, of course, it was actually a process of denial. Unfortunately, so is the book.

- C James Boyle 1991. Thanks go to Lauren Dame, Bob Gordon, Andrea Ball, Jae Won Kim, Jamin Raskin, Jim May, and Mark Hager. This article is dedicated to Burt Wechsler-a lawyer for the powerless since before I was born, who is a colleague of ten years and an inspiration for life.

1. Bork, The Supreme Court Needs a New Philosophy, ForTUNE, December 1968, at 140-1.

2. R. Bork, The Tempting of america: The Political Seduction of the Law (1990) [hereinafter cited in text]. 
Although this article was prompted by the publication of The Tempting of America, its subject is wider than that book alone. As I went further back into Mr. Bork's intellectual history, I discovered that the arguments in his most recent book followed a formula developed in his earlier writings. Like The Tempting of America, Mr. Bork's other works follow a lapsarian pattern-a tale of a fall from grace, coupled with a strategy for redemption. Mr. Bork identifies a state of corruption and decay in some institution or area of law. He traces the rot to a particular departure from the proper state of affairs, a willful violation of an authoritatively decreed scheme of things. He then prescribes a method which will allow us to escape our current fallen state and return to a condition of righteousness. Mr. Bork speaks strongly in favor of his method, pronouncing it "inescapable" or "unavoidable." Yet it is obvious that Mr. Bork's panacea has all the same features as the disease it is supposed to cure, despite Mr. Bork's lengthy and thunderous denial that this is the case. Eventually, he falls silent for a while, only to emerge two or three years later with some new, and newly ineluctable, redemptive method. The process then repeats itself. Readers familiar only with Mr. Bork's most recent writings will be surprised to find that in the past he has been, successively, a believer in libertarianism, process theory, judicial restraint, natural rights, neutral principles, law and economics, and two distinct forms of originalism. At the time, each of these theories was offered as the only possible remedy to the subjectivity and arbitrariness of value judgements in a constitutional democracy, while the other theories he had held, or was about to hold, were rejected out of hand.

The Tempting of America is, in one sense, the weakest and most obviously flawed of Mr. Bork's panaceas. He criticizes contemporary liberal constitutional jurisprudence for being arbitrary, politically biased, indeterminate, and ahistorical. Yet his prescription for cure-the philosophy of original understanding - is even more obviously flawed in these ways. Indeed, as the quotation at the beginning of this piece demonstrates, in an earlier incarnation he himself dismissed originalism as "naive." $\mathrm{Mr}$. Bork's rhetoric of denial must be correspondingly stronger and more thunderous. Yet in another sense, The Tempting of America marks a departure, albeit a fragmentary and contradictory one, from the endless process of denial. It reveals a shift to a different form of conservative thought, one that could be called pre-modern, or even post-modern. For these reasons, among others, it behooves us to pay more attention to Mr. Bork's most recent argument than its surface confusion and dogma might first appear to deserve.

Every Eden has its own forbidden fruit, its own great serpents. Mr. Bork's forbidden fruit is politics, his serpents are the members of a liberal 
elite in legal academia. More broadly, the villains of the piece are those in the "intellectual or knowledge class," "who work, however adroitly or maladroitly, with words and ideas" (p. 8). This class "tend[s] to have values antagonistic to a traditional, bourgeois society. It is not too much to say that these people see the Constitution as a weapon in a class struggle about social and political values" (p. 8). Despite the fact that he appears to work (however adroitly or maladroitly) with words and ideas, Mr. Bork is not a card-carrying member of this knowledge class. Like Karl Marx, he has managed to escape from the class-determined attitudes he describes.

Mr. Bork's plot is a relatively simple one. The knowledge class comes to realize that the values of the real Constitution (as interpreted by the Framers, their contemporary audience, and Mr. Bork) are hostile to their predilection for sexual freedom and egalitarian social reform. Unwilling to accept this limitation on their desires, they decide ${ }^{3}$ to subvert the true meaning of the document. They have a number of strategies to achieve this goal, including political opposition to judges who do not share their ideas of the Constitution. Understandably, Mr. Bork thinks this a particularly pernicious thing to do. But the liberal elite are not content merely to block those with whom they disagree. They wish to transform constitutional debate, to marginalize originalism by treating it as just one method of interpretation among many, perhaps to root it out altogether. The knowledge class receives help in its "heresy" (p. 7) from a number of well-meaning but unsophisticated judges who yearn to do justice, from a public unwilling to listen to discussions of constitutional theory, and from a perverse judicial tendency, as old as Marbury v. Madison, occasionally to ignore the manifest good sense of the philosophy of original understanding.

The knowledge class's success has cost the law dearly in terms of legitimacy. "Since the politicization of law has, for half a century, moved results steadily to the left, a very large number of Americans do not like those outcomes" (p. 2). The Tempting of America is, in effect, a clarion call to warn the general public of the dangers of continuing down this road and to rally Americans around the flag of originalism. It should be noted that originalism does not mean original intent. Mr. Bork used to think it blindingly obvious that the Constitution's true meaning was determined by the original intent of the Framers. Now he finds it equally obvious that the Framers' intentions are irrelevant and that the true meaning of the Constitution is determined by the way it would have been understood by the Framers' contemporaries. This new position is so

3. I use the word advisedly. Despite occasional comments to the contrary, Mr. Bork seems to envisage a set of conscious actions to "subvert" the Constitution, rather than the unconscious working out of a set of class-based ideas and attitudes. In this respect, of course, he parts company with Marx. 
obvious to Mr. Bork that he doesn't mind imposing it on candidates for the judiciary. Indeed, "[o]ne purpose of this book is to persuade Americans that no person should be nominated or confirmed who does not display both a grasp of and devotion to the philosophy of original understanding" (p. 9). At this point, one might legitimately ask Mr. Bork, "Isn't this the very thing for which you castigate the liberals? Isn't this the imposition of a politically-based loyalty oath for judicial method?" Mr. Bork's response seems to boil down to an assertion that his method, unlike those the liberals seek to impose, is right.

It would be a mistake to end our reading of Mr. Bork with this realization, however. His arguments may be shallow, dogmatic, ahistorical, logically flawed, and inconsistent with his own past writings. But this is only part of the story. This book reveals a great deal about the relationship between conservative ideology and the law, an issue which, given the current composition of the federal bench, will continue to be of considerable interest. The Tempting of America will take its place as the leading exposition of the philosophy of original understanding. For reasons I will give later, originalism is likely to be the only conservative legal theory with significant appeal to a mass audience. Thus, Mr. Bork's book has considerable political and iconographic significance.

The significance of the book becomes even clearer if we focus on the two warring sides of Mr. Bork's argument. The first and most obvious is an unsuccessful but relatively conventional attempt to satisfy the requirements of liberal rationalist social thought. In other words, he attempts to prove that the theory of original understanding is neutral, objective, unprejudiced and, in general, a rational analysis of the social world. The second and less obvious side of the book is the more interesting. Scattered throughout this work are fragmentary arguments and statements which, if pieced together, represent a fundamental conservative challenge to the framework of liberal rationalism, the very framework into which Mr. Bork has been trying to shoehorn his ideas. This challenge could be described as Burkean conservatism. Or, given its low opinion of the value of rationality, its critique of liberal epistemology, and its cut-andpaste approach to historical tradition, it could with equal justice be called "post-modern conservatism." Because it does not fit within the ruling epistemology, most readers will not even recognize this second argument as an argument. It is exactly for that reason that it deserves our attention.

Mr. Bork's book presents us-albeit in confused and contradictory form -with a strand of conservatism long neglected in the United States, a strand often identified with its most famous proponent, Edmund Burke. Thus, it gives us the opportunity to examine a striking historical parallel. Writing against the French Revolution, at the beginning of "the Age of Reason," Burke spoke out in favor of established hierarchies and 
a-rational tradition, and against the "delusive plausibilities of moral politicians." $4 \mathrm{He}$ argued that the attempt to understand the social world using only the "fallible and feeble" tools of reason was marked by both hubris and danger. Mr. Bork, writing in a post-modern era hailed by some as the twilight of reason, strikes exactly the same chords, though with less style and assurance. Is this a return to a pre-modern (or even the rise of a post-modern) conservatism? ${ }^{5}$

I will begin this article by discussing Mr. Bork's importance to current conservative legal theory. ${ }^{6}$ After concluding that the theory of original intent (and to a lesser degree, of original understanding) is one of the most popularly acceptable of the available conservative legal theories, I will devote the middle portion of the article to an examination of the intellectual odyssey which led Mr. Bork to make his way through each of those theories before holding the ideas he does now. I will prove, in fact, that Mr. Bork is the only conservative legal theorist who has held every conservative legal theory. Having shown how Mr. Bork developed his recent ideas about original understanding, I will assess their interpretive, historical, and logical merits. After demonstrating that Mr. Bork's most recent theory fails on all counts, I will discuss the structure that it has in common with his earlier work. Finally, using that structure as a tool, I will develop the part of his current ideas which challenges the epistemology of liberal rationalism and discuss its possible significance for conservative thought in general.

\section{Bork AND Conservative Legal Theory}

There have been enormous strides in conservative legal theory in

4. Burke, infra note 85 , at 125 .

5. As the reader will gather from this article, my interest is less in intellectual taxonomy, than in exploring certain similar challenges which both pre-modern (republican, Burkean) and post-modern thought present to the tradition of liberal rationalism. For the post-modern side of the story see HASSAN, POSTmodernISM: A Paracritical Bibliography, in PARACRITICISMS: SEVEN Speculations of the Times 39 (1973); J. KRisteva, Desire in Language (L. Roudiez ed. 1979). Post-modern work is marked by a skepticism about the limits of abstract, rational discourse (see, e.g. J. DerRIDA, Of Grammatology (1976)), and about the accuracy of political theories built around the notion of "the subject," a rights-holding individual divorced from culture, tradition, language, and history (see, e.g., M. Foucault, THE ORder of ThINGs (1976)). Stylistically it tends to rely on what David Kennedy calls "ironic conformity"-recreating tradition and history even as it uses them. Interestingly, Burkean conservatism is also marked by these three characteristics, although it is, of course, very different in other ways-stodgier in sentiment, more reactionary in declared political vision, less pretentious in persona, and infinitely superior in writing style. At first, the similarity seems bizarre. A moment's thought supplies a possible reason. Since each of these three characteristics was developed largely out of opposition to the dominant epistemology and political tradition of the Age of Reason, it is hardly surprising that they are encountered in works from both the beginning and the supposed end of that tradition. See Boyle, The Politics of Reason, 133 U. PA. L. REV. 685 (1985). Having pointed out that both Burkean and post-modern thought present a challenge to some of liberal rationalism's fundamental premises, rather than an argument within those premises, I have exhausted my interest in intellectual taxonomy and the reader need fear no further footnotes like this one.

6. In order to avoid endless quibbles about definition, I use the term "conservative" to refer to those who would use that term, among others, to describe their own political views. 
recent years. They were sorely needed. With some notable exceptions, ${ }^{7}$ conservative legal thought once consisted largely of bombast, red-baiting, and formalism. In the last fifteen years, that situation has changed dramatically. A number of distinct schools of conservative legal thought have appeared, providing conservative judges, administrators, and policy makers with a wealth of contradictory but persuasive advice on how best to use their newly-acquired power. The Tempting of America is best read as the leading statement of one of these schools. To understand its importance we must first look at the competition.

One of the most obvious contributions to conservative legal theory comes from the economic analysis of law. The Chicago school of law and economics has reconceptualized the legal system as a "rights market," where decision makers are asked to allocate rights to the person who would pay the most for them under conditions of perfect competition. ${ }^{8}$ This has the happy effect of favoring the rich over the poor, and all in the name of science. It also means that we can extend the ideology of the market to the last few areas, such as adoption, civil rights and the criminal law, which still have the temerity to resist it. In case anyone should imagine that this is merely an academic movement, it should be remembered that its chief proponent is now a federal judge. It is also instructive, if not actually frightening, to find that half of all federal judges have already attended corporate-funded courses in law and economics, arousing considerable concern over the ethical propriety of their actions.

Alternatively, for those less enamored of the dismal science, there are libertarian legal theories. Libertarians place the takings clause at the center of the Constitution, and read it broadly to cover much of governmental activity. "All regulations, all taxes, and all modifications of liability rules are takings of private property prima facie compensable by the state." They argue that the judiciary should move towards a minimalist state by striking down everything within the broad reach of the takings clause. This analysis results in the conclusion that the New Deal is unconstitutional, as are the minimum wage, worker's compensation, rent control, social security and progressive taxation. Sadly, the libertarian concern for takings of private property does not extend to those who have suffered the greatest losses in the past-Native Americans and African Americans in particular.

7. A. Bickel, The Least Dangerous Branch (1962).

8. See R. Posner, The Economic analysis of Law (1986); M. Polinsky, AN INTRODUCTION TO ECONOMIC ANALYSIS (1989); Baker, The Ideology of the Economic Analysis of Law, 5 J. Pril. \& PUB. AfF. 3 (1975); Kennedy, Cost-Benefit Analysis of Entitlement Problems: A Critique, 33 Stan. L. Rev. 387 (1981); Boyle, The Politics of Reason: Critical Legal Studies and Local Social Thought, 133 U. PA. L. ReV. 685 (1985).

9. R. Epstein, Takings: Private Property and the Power of Eminent Domain 95 (1985). 
Both law and economics and libertarianism require a degree of "judicial activism" which undermines the notion that conservatives are automatically proponents of "judicial restraint." Nevertheless, some still believe that the first job of a conservative legal theory is to limit the power of the judiciary. To this end it has been suggested that Congress should be capable of overruling federal or Supreme Court decisions, or that a seven member majority on the Court should be required to strike down federal or state law. ${ }^{10}$ Legislation was also proposed which would have made it an impeachable offense for federal judges to order governmental expenditures for a specific purpose, when a legislature has not authorized and appropriated funds for that purpose. ${ }^{11}$ Those who prefer brief solutions will like the suggestion that Congress should simply remove "controversial political and social questions from the appellate jurisdiction of the Supreme Court."12 Since every issue which comes to the Supreme Court seems like a controversial social issue to someone, such a solution would have the indirect benefit of making a valuable plot of real estate on First Street N.E. available for development.

Social conservatives have been less prominently represented in the academy, but no less influential in decision-making. Members of this group have led the attack on Roe v. Wade, convinced the Supreme Court that there is no constitutional bar to criminalizing all sexual acts beyond the heterosexual missionary position, persuaded the Justice Department to oppose affirmative action, and held out the possibility that divorce should be restricted and perhaps abolished. "In a case of a traditional church marriage, where the couple has exchanged the usual vows 'for richer or poorer, in sickness and in health, till death us do part', there is no reason why they should not be held to their contract."13 A passage from the same work gives some notion of the social conservative attitude towards equal opportunity law and women's rights.

The strains imposed on the family by equal opportunity are enormous-husbands competing with their own wives, men and women entering into marriage "so long as love shall last," mothers feeling compelled to abandon their families for a career or to satisfy their sexual appetites. The real effect of this collective delusion of women's rights is only to reduce the once sovereign family to a support system for various governmental agencies. ${ }^{14}$

10. A useful summary of such proposals can be found in Stanmeyer, Judicial Supremacy, in THE New Right Papers 142, 163-65 (R. Whitaker ed. 1982). Professor Stanmeyer is in favor of some, but not all, of these suggestions. As his title suggests, his concern is most directly with judicial supremacy rather than judicial activism, though it seems clear that he believes the two to be integrally related.

11. Id. at 163 .

12. Id. at 164 .

13. Fleming, Old Rights and the New Right, in The New Right PaPERS 180, 196 (R. Whitaker ed. 1982). Dr. Fleming later extends his argument to civil ceremonies.

14. Id. at 196-97. 
On the strategic level of national politics, Bork's book is important precisely because so many people would find these other conservative legal movements to be either too complicated or too wacky. Perhaps both. I hasten to say that this is not a judgement about the actual merits of conservative ideas. Judge Posner gets justifiably upset when people ignore the rest of his brilliant and prodigious opus and focus on only his baby-selling article, even comparing his suggestions to Swift's $A$ Modest Proposal. There is certainly intellectual substance to the idea that markets ration scarce resources-in this case, babies-better than do bureaucracies. Nevertheless, there is an undeniable reaction of moral and emotional outrage at economic discussions of the efficient level of crime or the economics of the baby shortage. The depth of outrage at suggestions like this makes it likely that, as a popular national platform for conservative legal reform, law and economics has even less of a chance than bimetallism. Behind the scenes, of course, it is likely to be more and more important.

As for the libertarian ideal, it is certainly true that property exercises a peculiar fascination over the affections of mankind. Nevertheless, it is hard to imagine a popular political or legal movement built around the idea that the New Deal is unconstitutional, or that the takings clause is the center of the Constitution. An unalloyed philosophy of judicial restraint is also unlikely to have much appeal, either to the public or to conservative judges revelling in their new found powers.

When it comes to social conservatism, I have found that a lot of Americans, and not merely the members of Mr. Bork's knowledge class, have a yen for sexual freedom and "the delusion of women's rights." The author who used that phrase and then suggested abolishing divorce, described his creed in the following way; "when a Southerner calls himself a conservative, he is usually thinking of a way of life, of a social and moral order for which the people of the 1860's went to war."15 Correct me if I am wrong, but wasn't the name of that social and moral order "slavery?" While I can believe much of American politics, I cannot believe that slavery, or baby-selling, or even the abolition of the New Deal (shortly followed by the Supreme Court) would form the basis of an extraordinarily popular conservative legal movement. And that is where Mr. Bork comes in.

Mr. Bork's book is tailor-made for popular appeal. It is weighty enough to convince those who are not familiar with the material he discusses, and shallow enough to be capable of quick summary in a talk show or newspaper article. As I will show in the next section, the arguments against Mr. Bork's ideas are overwhelming, but sometimes complicated or dependent on a base of detailed historical knowledge. For these

15. Id. at 184 . 
reasons, the opposing arguments are unlikely to fare well in the orgy of narcissism, cliche, and half truth which masquerades as public debate on the nation's airwaves. But any detailed, scholarly, or merely honest analysis of Mr. Bork's ideas reveals a jurisprudence of dogma and sound-bites and a version of history which bears the same relationship to the Framer's ideas that Busch Gardens bears to Europe.

In one view, perhaps the dominant view, Mr. Bork's most recent book is an alternately defensive and opportunistic response to his confirmation hearings. The story goes something like this: Mr. Bork is a thoughtful legal scholar and must surely recognize the problems with his theory. He himself used to criticize originalism, before it became flavor of the month at the Justice Department. Yet consider the alternatives open to him. He can acknowledge that his theory of constitutional interpretation is both incoherent and unworkable. But to do so would be to legitimate the painful criticism to which he was subject during the hearings. Alternatively, he can turn his back on scholarship and real history, becoming instead a revered video pundit of the right, bearing the scars of honorable battle and a theory that can be explained between commercial breaks. Who can be surprised when he chooses the latter course? Who can be surprised to find that his theory fails to confront the objections raised to it? Who can be surprised that his book consists instead of a process of denial-denial of philosophical problems, historical problems, logical problems, and finally, denial of personal inconsistency?

Yet there is another way of viewing this book. Perhaps The Tempting of America should not be seen as the defensive and disingenuous product of the confirmation hearings. Instead, it may best be seen as the culmination of a prominent conservative's intellectual odyssey, the end of a trek through each of the prevalent schools of conservative legal thought. In the next section I will suggest that Mr. Bork has measured each of the ideas he has held by its ability to offer a coherent conservative vision of how a society is to be run if values are not subject to rational discussion. If this is true, then the fact that he ends up with the theory of original understanding is particularly fascinating. What does originalism, which seems the weakest of the conservative theories, offer that the others do not?

\section{IS BORK A BORKEAN?}

Mr. Bork has had a colorful career. Before becoming a judge, he was a practicing lawyer, a Yale law professor, and then a Solicitor General of the United States. His term in the latter office "included some duties not listed in [the] job description, among them writing briefs against Vice President Spiro Agnew ... and the firing of Special Prosecutor Archibald Cox in what was known as the Saturday night massacre" (p. 272). Certain members of the knowledge class suggested during Mr. Bork's confir- 
mation hearings that the latter act did not reflect well upon him. He feels, however, that " $[t]$ hese are stories that may be left for another time" (Id.). I will bow to his wishes, turning instead to the changes in his intellectual position over the last twenty-five years.

Mr. Bork's intellectual history is a fascinating odyssey through all of the major theories of twentieth century conservative legal thought. At one time or another, Mr. Bork has held them all-and always passionately. In this sense, he is a conservative Everyman, and his odyssey presents the development of conservative legal thought in microcosm. This makes his current position all the more interesting.

In 1963, when conservatives were worried that Congress might force whites to open their hotels and restaurants to Blacks, Mr. Bork was a libertarian with a high regard for individual freedom of association. He had this to say about the Interstate Accommodations Act:

The legislature would inform a substantial body of the citizenry that in order to carry on the trades in which they are established they must deal with and serve persons with whom they do not wish to associate.... The fact that the coerced scale of preferences is said to be rooted in a moral order does not alter the impact upon freedom. In a society that purports to value freedom as an end in itself, the simple argument from morality to law can be a dangerous non sequitur. ... The principle of such legislation is that if $I$ find your behavior ugly by my standards, moral or aesthetic, and if you prove stubborn about adopting my view of the situation, I am justified in having the state coerce you into more righteous paths. That is itself a principle of unsurpassed ugliness. ${ }^{16}$

Five years later, when he published Why I Am For Nixon, ${ }^{17}$ and The Supreme Court Needs A New Philosophy, ${ }^{18} \mathrm{Mr}$. Bork's judicial philosophy was largely cast in the form of a critique of the Warren Court, whose result-oriented jurisprudence had tempted judges with a knowledge they were forbidden to possess. The latter article is particularly interesting. In it, Mr. Bork argued that "[t]he Warren Court . . . challenges us to think again whether there is or can be any substance to the distinction between law and politics." 19 The article goes in search of some theoretical basis for that distinction. Bork concluded that it is "naive" to take the position which he now espouses, that is, to insist simply that the Court 'give the Constitution its 'true meaning.' The possibility implied by those comforting phrases does not exist." 20 In a passage which will

16. Bork, Civil Rights-A Challenge, The New Republic, Aug. 31, 1963, at 21.

17. Bork, Why I Am For Nixon, The New Republic, June 1, 1968, at 19.

18. Bork, The Supreme Court Needs a New Philosophy, ForTUNE, Dec. 1968, at 138.

19. Id.

20. Id. at 140 . 
surely surprise some of his more recent readers, Bork even quoted Robert Penn Warren for the truth of the legal realist view of law.

Every thoughtful working lawyer has shared the insight expressed by Willy Stark, the Huey Long-like politician in All the King's Men and a legal realist if ever there was one. "The law," he said, "is like a single-bed blanket on a double bed and three folks in the bed and a cold night. There ain't ever enough blanket to cover the case, no matter how much pulling and hauling." The question, then, is not whether courts should make law, but how and from what materials. $^{21}$

Answering his own question, Mr. Bork tried and rejected a number of alternative "materials." Relying on the traditional materials, "the text of the Constitution, history and precedent," will not solve the realist dilemma. "[S]ometimes they dictate results. But more often these sources suggest that the Court must enter a field and yet do not answer the important questions found there." Probably the most striking passage is the one quoted at the beginning of this article, in which Bork specifically rejects the originalist position.

History can be of considerable help, but it tells us much too little about the specific intentions of the men who framed, adopted, and ratified the great clauses. The record is incomplete, the men involved often had vague or even conflicting intentions, and no one foresaw, or could have foreseen, the disputes that changing social conditions and outlooks would bring before the Court. ${ }^{22}$

Bork concluded that Willy Stark and the Yale legal realists were "dead right about the inadequacy of the traditional sources of law."23

The new philosophy Mr. Bork offered was an interesting hybrid. It was a kind of process theory which combined an argument like Bickel's for judicial restraint with a Wechslerian argument for judicial activism when necessary to safeguard deductively-generated "natural rights." Mr. Bork stitched these disparate elements together with his usual conviction and self-assurance.

Where the Constitution does not thrust it into a field, a restrained Supreme Court would deal with the processes by which the policies of representative institutions are made and applied, rather than with the substance of the policies. Intervention coupled with refusal to pass on substance does not entail a contradiction. . . . In his book The Least Dangerous Branch, Professor Alexander Bickel of Yale has analyzed the rich and subtle repertory of judicial techniques available to educate, to frame, and to expose issues for other

21. Id.

22. Id. at 141 .

23. Id. 
branches of government, to require them to face up to hard choices and their consequences. Restraint entails not so much a reduced as a different role for the Court, one better suited to democratic society than the role now played by the Warren Court. ${ }^{24}$

The traditional conservative's preference for judicial restraint is subject to the Madisonian imperative that the court intervene in order to protect minorities from majorities.

A desire for some legitimate form of judicial activism is inherent in a tradition that runs strong in our culture, a tradition that can be called "Madisonian." We continue to believe that there are some things no majority should be allowed to do to us, no matter how democratically it may decide to do them. . . . [T]here are some aspects of life a majority should not control . . . coercion in such matters is tyranny, a violation of the individual's natural rights. ... Clearly, the definition of natural rights cannot be left to either the majority or the minority. ... This requires the Court to have, and demonstrate the validity of, a theory of natural rights. ${ }^{25}$

The theory of natural rights turns out to be more "conventional" than "natural." "Working in the method familiar to lawyers trained in the common law, the judge can construct principles that explain existing constitutional rights and extrapolate from them to define new natural rights." ${ }^{26}$ Having rejected as "naive" a search for the historically defined lines the elder Mr. Bork will find so easily, the younger Mr. Bork offers less tangible, "intersubjective" constraints on this process.

In proceeding to derive new rights, the courts must be controlled by the methods and disciplines that lawyers call craftsmanship. . . . Only in this way, so far as I can see, can we begin to meet the plea made by Professor Herbert Wechsler of Columbia for "neutral principles" of constitutional law. ${ }^{27}$

If readers are a little surprised by this realist, activist Bork, who began his analysis from the necessity of courts making law, they will also be surprised by the "neutral" set of natural rights he managed to "derive." In 1968, it was obvious to Mr. Bork that the first amendment, correctly interpreted, protected not only political but also non-political speech. ${ }^{28}$ The implications, however, went much further:

[N]on-political speech too, of course, is entitled to some degree of constitutional protection. Brandeis cited other values of speech that are not unique to the political variety. For both speaker and hearer, speech may be a source of enjoyment, of self-fulfillment, of personal

24. Id. at 166,168

25. Id. at $168-70$.

26. Id. at 170 .

27. Id.

28. Id. at $168-70$. 
development. It is often mundane or vulgar or self-serving, but it may be exalted, inspired by the highest motives. It may affect attitudes that ultimately impinge on the political process. All this has implications that, though generally overlooked, seem inescapable. For in these respects nonpolitical speech does not differ from nonverbal behavior, whether it customarily bears the label "sexual," "economic," "artistic," or some other. One could argue, then, that all human behavior should be entitled to the same level of constitutional consideration, the same judicial scrutiny of governmental regulation, that is currently afforded to nonpolitical speech. ${ }^{29}$

After generalizing first amendment protection to all human behavior, Mr. Bork modestly offered a way to draw a line between the wishes of the majority and the rights of the minority.

[M]oral disapproval alone cannot be accepted as a sufficient rationale for any coercion. . . . The Court can draw a line, applicable to many more situations than the "right of privacy" enunciated in Griswold, by ruling that the majority may prohibit morally or aesthetically offensive nonpolitical behavior where the public must observe it, but cannot reach conduct out of sight on such a rationale. Both majority and minority may feel some pain at their respective limitations, but the line does preserve an enclave of freedom while minimizing the pain felt by the majority. ${ }^{30}$

There is a certain poignancy in this confident display of Mr. Bork's libertarian persona, akin to the feeling one has looking at photographs of a doomed individual, still full of vigor, unaware of the fate that awaits him. By 1990, Mr. Bork would believe that a majority must legislate morality if it is not to "dissolve social bonds" (p. 249). In 1968, however, he could hardly have championed libertarianism more vigorously. At that moment, a constitutional order created by Mr. Bork would probably have resembled Professor Epstein's world, where "all regulations, all taxes, and all modifications of liability rules are takings of private property prima facie compensable by the state" 31 and where the acceptable reasons for state intervention in individual behavior are few indeed. This position is the logical conclusion of the ideas Bork held in 1963 when he wrote that the prohibition of racial exclusion in public lodging embodied a "principle of unsurpassed ugliness" 32 because it interfered with individual liberty. It is hardly surprising, then, that five years later, he thought it "inescapable" that all human behavior should be granted constitutional protection of the same kind as non-political speech. The quotation above is perhaps the clearest example of the direction of his thought.

29. Id. at 170 (emphasis added).

30. Id. at 174.

31. R. EPSTEIN, supra note 9.

32. Bork, supra note 16. 
Notice how careful he is to carve out a sphere of private action free from public moral regulation. The majority can interfere on moral grounds only in what it can see, and even then there is lower level first amendment protection. The implications of this position are dramatic. Using this sort of analysis, Bowers v. Hardwick ${ }^{33}$ would certainly be overruled, and there would be an overwhelmingly strong argument in support of Roe v. Wade. ${ }^{34}$

But after this five-year period of holding to the same line, Mr. Bork's peripatetic intellect was straining at the leash. By 1971, the libertarian side of Mr. Bork's ideas had crumbled, while reliance on Wechsler's theory of "neutral principles" had increased. The change was hardly subtle. Nevertheless Bork described each of his different positions as unavoidable. Three years earlier he had believed it inescapable that the first amendment covered all human behavior. Yet in his 1971 Indiana Law Journal article, he could not see how to avoid the conclusion that the first amendment covered only political speech, narrowly defined. ${ }^{35}$ The principles of libertarianism seemed to have vanished from his thought.

Mr. Bork confessed to his change of heart, at least insofar as it implied a reversal of his position on Griswold v. Connecticut. In 1968, together with other commentators, he had thought that case "a salutary demonstration of the Court's ability to protect fundamental human values." 36 By 1971 Bork thought Griswold an "unprincipled decision," both its derivation and its definition being "utterly specious." 37 He offered as "extenuation" for his change of heart that "at the time I thought, quite erroneously, that new basic rights could be derived logically by finding and extrapolating a more general principle of individual autonomy underlying the particular guarantees of the Bill of Rights." 38

As Mr. Bork's libertarian sentiments were gradually abandoned for

33. 478 U.S. 186 (1986) (upholding the Georgia statute criminalizing sodomy).

34. 410 U.S. 113 (1973). In fact, it is surprising how closely Mr. Bork's ideas mirror those of the majority opinion in Roe, particularly in the way that liberty of choice is developed through an idea that private choices are immune from majority scrutiny. Despite his later hostility to the "right of privacy," Mr. Bork himself thinks that his expansion of the rationale of first amendment doctrine goes considerably beyond Griswold v. Connecticut, 381 U.S. 479 (1965). If economic activity is given the protection associated with non-political speech, what about reproductive choice? The same point can be made about his hostility to civil rights legislation. If interfering with whites' rights to refuse black customers involves a "principle of unsurpassed ugliness," what about interfering with a woman's control of her body? Finally, under Mr. Bork's public/private distinction, if an abortion were carried on in private, even if a majority found it morally abhorrent, it would be protected. It would appear that Mr. Bork's only possible response to this result would be to class abortion as a "crime" and thus free it from his libertarian principles. Such a response exposes the circularity in both sides of this argument (since the question of classification decides the analysis rather than following from it) and also means that he must engage in substantive discussion of individual issues, the very thing he claims to avoid.

35. Bork, Neutral Principles and Some First Amendment Problems, 47 IND. L.J. 1, 35 (1971).

36. Id. at 8 (citing Bork, supra note 1).

37. Bork supra note 35 , at 9 . His disillusionment did not stop there. Nineteen years later, Griswold seemed to him "a constitutional time bomb," id. at 95, a case that rivalled Dred Scott v. Sandford, infra note 79 , in its awfulness.

38. Id. at 8 . 
"neutral principles," his ideas about interpretation were undergoing a similar metamorphosis. In $1968 \mathrm{Mr}$. Bork had thought it "naive" to imagine we could solve our problems merely by appointing judges determined to give the Constitution its "true meaning." "The possibility implied by these comforting phrases does not exist. ..."39 He had specifically pointed out that an originalist historical search told us "too little about the specifics." At that time, he gave as an example the difficulty of determining the level of generality of the Fourteenth Amendment. "History shows us that the equal protection clause (ratified a few years after the Civil War) grew out of a concern about racial equality, but in crucial respects the record leaves us unsure what was meant by equality and how far beyond race the guarantee was intended to reach." ${ }^{40}$ Does it mandate "black equality," "racial equality," or some wider vision? By 1971, history had become considerably clearer, so that Mr. Bork could say "[O]ne thing the Court does know: [the fourteenth amendment] was intended to enforce a core ideal of black equality against governmental discrimination."41 As the years passed, the record was to become clearer still.

In 1980, Paul Brest made the same criticism of original understanding that Bork himself had made in his 1968 article: the approach leaves open the level of generality of the constitutional provision, and therefore the judge must choose a level of abstraction. When Mr. Bork responds to Brest's article in 1990, there is no trace of the methodological problems which had once caused him to see indeterminacy in texts, precedents, and historical records. "The role of a judge committed to the philosophy of original understanding is not to 'choose a level of abstraction.' Rather it is to find the meaning of a text-a process which includes finding its degree of generality, which is part of its meaning" (p. 149). The methodological confidence is accompanied by some interesting substantive convictions about equal protection. Women and gays will have to make do with a lower-level scrutiny as to whether any discrimination is "reasonable." In the case of gays, at least, reasonableness will almost always be found. "Social treatment of homosexuals is based upon moral concerns and it would be difficult to say that the various moral balances struck are unreasonable" (p. 150). This is a far cry from the libertarian who wanted to broaden the protection offered by Griswold to all human behavior.

As Mr. Bork's libertarianism waned and his theory of interpretation changed, an associated shift in his moral epistemology was taking place. Two sentences from his famous Indiana Law Journal article sum it up:

Unless we can distinguish forms of gratification, the only course for a principled court is to let the majority have its way in both

39. Bork, supra note 18 , at $140-41$.

40. Id.

41. Bork, supra note 35, at 14-15. 
cases. ... There is no principled way to decide that one man's gratifications are more deserving of respect than another's or that one form of gratification is more worthy than another. ${ }^{42}$

In a footnote he elaborates: "The impossibility is related to that of making interpersonal comparisons of utilities." ${ }^{\prime 43}$ The conclusion that economists draw from this premise is that matters of value must be left to the market. In the Indiana article, Mr. Bork argues that they must be left to the majority unless trumped by an overriding neutral principle derived from the Constitution using the Wechslerian tools of generalization and abstraction. ${ }^{44}$ In The Tempting of America, the formulation is the same but the content has changed: questions of value must be left to the majority unless the original understanding produces a principle that trumps them. Mr. Bork now has the form of his basic argument, a form that can be filled using his method of the moment.

So far, we have seen Mr. Bork hold most of the available conservative legal theories I discussed earlier. He advocated in turn libertarianism, traditional judicial restraint, judicial activism to enforce natural rights, and Wechsler's theory of neutral principles. The only schools of thought missing from the list are the economic analysis of law, social conservatism, and the philosophy of original intent. These, though, were soon to follow.

During this entire period, Mr. Bork had been hard at work on the articles later published as The Antitrust Paradox, which was finished in 1978. The shibboleths of his argument looked reasonably familiar.

Within the limited frame for observation provided by antitrust, therefore, it is worth noting that the general movement has been away from legislative decision by Congress and toward political choice by courts, away from the idea of competition and toward the older idea of protected status for each producer, away from concern with general welfare and toward concern for interest groups, and away from the ideal of liberty toward the idea of enforced equality. ${ }^{45}$

Mr. Bork believed these trends to be "ultimately incompatible with the preservation of a liberal capitalist social order." 46 His prescription was a fascinating one. At first it appears that Mr. Bork was proposing a form of originalism in which "political choice by courts" is replaced by "legislative decision by Congress." The question then becomes, "Should the antitrust statutes be enforced according to the original intent of Con-

\footnotetext{
42. Id. at 10.

43. Id. at n.20.

44. The Wechslerian method is required because of the vagaries of historical interpretation. Mr. Bork is now willing to concede authoritativeness to the power of original intent, but has the same critical view of its determinacy. "It is the fact that history does not reveal detailed choices . . . that permits, indeed requires, resort to other methods of interpretation." Id. at 13.

45. R. Bork, The Antitrust Paradox (1978).

46. Id.
} 
gress?" Mr. Bork has some doubts. "Antitrust" he tells us, "is a subcategory of ideology."47

[Its] basic premises are mutually incompatible, and because some of them are incorrect, the law has been producing increasingly bizarre results. . . . The law must either undergo a difficult process of reform, based upon a correct understanding of fundamental legal and economic concepts, or resume its descent to the status of an internal tariff against domestic competition and free trade. ${ }^{48}$

At this point one might wonder where this "correct understanding" would come from. A later Mr. Bork would surely rule out any source but Congress's actual intentions, no matter how mistaken. Today's Mr. Bork would look to the way the statutes were understood at the time of passage, and not to subjective intentions. The Mr. Bork of 1968 might have believed it possible to "derive" a new antitrust policy "logically by finding and extrapolating a more general principle" underlying the "particular guarantees" of the antitrust statutes, but the Mr. Bork of 1971 had already pronounced that method erroneous. ${ }^{49}$

As it turns out, the source of the "correct understanding" is something of a mixture. Much of the basic argument in The Antitrust Paradox is historical, but it is a history which serves Mr. Bork's ends. Most historians would agree that one of the goals of the antitrust rules was to prevent the concentration of economic power in American society. Those who wrote and passed the statutes believed enormous concentrations of economic power to be inherently subversive of the American republic. But this is exactly the kind of egalitarian claptrap Mr. Bork will not tolerate. Consequently, he feels free to apply the wisdom of modern economic analysis to rectify the errors of Congress and the courts. ${ }^{50}$

Bork argues that the current principles of antitrust were never confirmed empirically, but admits that they do have history on their side. "What is true is that our ideas are old; they carry whatever credentials time alone can confer. The years 1890 to 1914 witnessed the origin of every major theory that drives and directs the evolution of antitrust to this day." 1 Mr. Bork does not wholly reject the intentions of the framers. "The concept of legislative intent may be artificial, but it is also indispensable. Besides the construct is not wholly arbitrary." 52 But he does not want the actual, raw, confused goals that those who passed the

47. Id. at 3 .

48. Id. at 7 .

49. Bork, supra note 35 , at 8 .

50. It is interesting to compare Mr. Bork's current reverence for the original understanding of the Constitution with his polite condescension towards the authors of the Robinson-Patman Act, who "may well have been moved by an NRA-style philosophy" and an ignorance of economic consequences. BORK, supra note 45 , at 63 .

51. Id. at 15 .

52. Id. at 57. 
statutes either had, or were understood at the time to have had. What he wants is a legislative intent purified and refined in the fires of modern views about economy and society. "A legislature may never address the issue of ultimate policy goals and yet write a law whose various categories and distinctions can be explained only by a particular policy. That policy may then quite legitimately be said to have been intended by the legislature, even though not a single member articulated it to himself. ${ }^{53}$ From this "not wholly arbitrary" vision of legislative intent and a modern lawyer's vision of microeconomics, Mr. Bork can discern amoung the many goals of the antitrust statutes "only one legitimate goal, and that goal can be derived as rigorously as any theorem in economics." 54 The goal is "consumer welfare." It is fascinating to contrast Mr. Bork's willingness to supplement the original intention or understanding of the antitrust statutes with his advocacy of original understanding in constitutional interpretation. He speaks dismissively of the "primitive state of the law's economic doctrines"5s and moves quickly to deploy the weapons of modern economic analysis. Yet when contemporary legal scholars take a similar approach to the Constitution, bringing to higher levels of generality principles which have only "whatever credentials time alone can confer," or which are thought to be morally reprehensible, Mr. Bork considers it the worst kind of sacrilege.

It is no answer to say that antitrust law is merely statute law. Mr. Bork explicitly argues that original understanding applies across the board as a legal philosophy. Another possible response would be to argue that the original understanding can be supplemented by developments in a supposedly value-free field such as economics, but not by changes in moral attitudes. Even if we accepted the dubious epistemological premise, this would get Mr. Bork no further. Jim May has demonstrated the impossibility of this position. ${ }^{36}$ In fact, the authors of the antitrust statutes had a perfectly coherent economic theory which simply favored values different from those embodied in current theory. The statutes and early cases rested not merely on "open-ended subjective populism" but instead on the classical economics propounded by the likes of Wayland and Bowen, and eagerly absorbed by a generation of legislators and judges. ${ }^{57}$ This vision gave rise to "analyses that, while faithful to one generation's economic vision, could be found not only

53. Id.

54. Id. at 51

55. Id. at 134 .

56. See May, Antitrust Practice and Procedure in the Formative Era, 135 U. PA. L. ReV. 496 (1986).

57. For a more general account of the impact of law on classical and neoclassical economic thought, and of economics on law, see Kennedy, The Role of Law in Economic Thought: Essays on the Fetishism of Commodities, 34 AM. U.L. REv. 939, 940-967 (1985); May, Antitrust in the Formative Era: Political and Economic Theory in Constitutional and Antitrust Analysis 1880-1918, 50 Oнго ST. L.J. 258, 258-287 (1989). 
faulty, but practically unintelligible by a later generation of antitrust analysts influenced by a very different vision of the nature of economic reality."58

If one puts a multi-goal antitrust policy to the test of an economic theory which postulates "consumer welfare" as the highest good, it will fail. But what happens if, as the philosophy of original understanding requires, we test it according to the values of the economic theory reigning at the time? Antitrust policy fares rather better by the lights of classical economic theory, which guards against the distortion of "natural processes" and builds on the indissoluble connection between political morality and economics. Even if original understanding does not force us to look to the economic wisdom at the time the antitrust statutes were written, Mr. Bork has no way of proving that his economics serves preferable values. Why is consumer welfare better than economic decentralization? "There is no way of deciding these matters other than by reference to some system of moral or ethical values that has no objective or intrinsic validity of its own and about which men can and do differ." 59 Mr. Bork is caught once again in nets of his own devising.

\section{The Flight from Value}

The dilemma revealed in this last quotation is the beginning of the Ariadne's thread which will lead us through the maze of Mr. Bork's ideas. To some, the revelation that Mr. Bork has espoused so many different legal theories, and done so with such vigor, would suggest that he is merely a conservative ideologist-for-hire, producing whatever legal theory is necessary to win the political debates of the moment. Though I deeply disagree with Mr. Bork about almost everything, I think this would be unfair. I believe that Mr. Bork's long march through the halls of conservative legal theory represents a sincere, almost anguished, attempt to deal with a single dilemma: If there is no way of deciding matters of legal interpretation except "by reference to some system of moral or ethical values that has no objective or intrinsic validity of its own," then what of the rule of law itself, or of the line between law and politics?

In my view, this recurring concern is the most important recurring theme in Mr. Bork's writings. (Although, as I will argue later, The Tempting of America may mark a partial break with the rest of the canon.) In Civil Rights-A Challenge, this concern led him to believe that Congress had no business overpowering the value judgements of racist hotel keepers with value judgements of its own. If value judgements are truly arbitrary, the law should carve out spheres of liberty in

58. May, supra note 56 , at 593

59. Bork, supra note 35 , at 10. 
which people can decide for themselves. In The Supreme Court Needs a New Philosophy, Mr. Bork's concern was expressed in terms of a commitment to "process" rather than substantive (and arbitrary) value choice, at least in those areas in which the political process functioned well. Where it did not, Mr. Bork advocated a craftsmanlike derivation of new "natural rights" underlying the liberties which must be protected from majorities. Again, those liberties must be protected precisely so that a minority could exercise its own arbitrary values in private, free from the arbitrary value judgements of the majority. In his Neutral Principles article, we see the same concern in a commitment to protecting only those rights for which a Wechslerian "neutral principle" could be generated, and to letting the majority express its unreviewable value judgements everywhere.

In The Antitrust Paradox that concern leads Mr. Bork, as it has led a good many conservatives recently, to reject the contentious and ideologically loaded choices he saw in the law and to embrace instead the scientific certainties apparently offered by microeconomic analysis. Admittedly, Mr. Bork tells us that the microeconomic theory we need is not to be confused with the contradictory theories actually produced by economists. That belief is an understandable mistake of the lay mind. "The layman is likely to think that economic theory is what any economist theorizes, but of course it is not. If it were, we should have to believe that there are dozens or hundreds of mutually incompatible versions of economic theory, each as good as any other."60 That would be intolerable because the point of this whole process was to introduce a scientific and unchanging criterion, a goal of antitrust that "can be derived as rigorously as any theorem in economics." There is no room for the suggestion that economics itself might embody unexplained value choices or be subject to internal professional dispute. Consequently, "the judge, legislator or lawyer cannot simply take the word of an economist in dealing with antitrust, for the economists will certainly disagree."61 When his quest for a constitutional interpretation free from value judgments leads him to seek a foundation in history rather than economics, Mr. Bork will take a similarly dismissive view of the kind of history that historians produce.

Here then, is the heart of Mr. Bork's intellectual mission-to offer a convincing conservative answer to the central question of liberal society. How can we run a society if value judgements are subjective and relative? Each of his theories seems to offer the hope of answering this question, but each eventually collapses, driving him to the next, "inescapable" set of ideas. As a libertarian, he believed we could leave value judgements to

60. BoRK, supra note 45 , at 117.

61. Id. at 118. 
individuals, but he encountered the difficulty of drawing the lines inside which individuals could exercise their arbitrary values. As an advocate of traditional judicial restraint, he believed that those choices could be left to the political process, if they were first properly framed by the court. Yet he doubted that the line between those issues that the court must solve and those that it can leave to another institution could be neatly drawn. When he came under the sway of Herbert Wechsler's theory, he accepted that courts might actually decide hard questions provided they used a principle which is "neutral" as to visions of the good. When he wrote The Antitrust Paradox he believed that the value judgements expressed by the legislature could be purified by the scientific wisdom of economic analysis, and could thus provide legislative goals as rigorously derived as any theorem of economics. His final turn has been towards originalism, the theory he once scorned as naive. Originalism "solves" the problem of value in constitutional theory by claiming that it does no more than apply the Framers' value judgements, and that those value judgements are actually historical facts, not values at all. Since liberal epistemology accepts the possibility of rational discussion about facts, the problem of value for constitutional theory is solved. Or is it?

\section{ORiginal INTENT}

The better known variant of originalism, and the one that Mr. Bork first adopted and held as recently as 1986, was the philosophy of original intent. ${ }^{62}$ The Constitution means what the Framers (or perhaps the Framers and ratifiers) meant it to. This is the most influential version of originalism, the judicial philosophy championed by recent Attorneys General. While it may be most popular, it is also the easiest to blow out of the water. Listing the arguments against it is the kind of arduous, lengthy, and repetitive task which Victorians believed suitable for the rehabilitation of convicts. I undertake it here in the hope of acquiring virtue.

First, the idea that the intention of the original author must govern the meaning of the text is simply false as both a practical and a philosophical matter. In law and in life generally we use many different interpretive criteria to establish what something "means." Second, it may well be that the only true way to follow the intent of the Framers is by not following their intent. There is strong historical evidence that the Framers did not wish their intentions to bind future generations. Professor $\mathbf{H}$. Jefferson Powell has shown, in his article The Original Understanding of

62. See, e.g., Bork, The Constitution, Original Intent and Economic Rights, 23 SAN DIEgo L. REV. 823 (1986). "I wish to demonstrate that original intent is the only legitimate basis for constitutional decision making." Id. "The only way that the Constitution can constrain judges is if the judges interpret the document's words according to the intentions of those who drafted, proposed, and ratified its provisions and various amendments." Id. at 826. 
Original Intent, ${ }^{63}$ that the Framers had a vision of interpretation governed by the traditional hermeneutic methods of the common law rather than by the simple notion of original intent. Third, records we do have of the Framers' intentions are often contradictory, indeterminate, or both. Thus, the difficulty of reading the text of the Constitution is merely shifted to reading the historical records. Fourth, in those few areas where original intent is clear, it is sometimes morally outrageous. Any protagonist of original intent must confront the dubious moral acceptability of allowing constitutional interpretation to be governed by the beliefs of these men, many of whom believed ardently in slavery and the innate inferiority of women. Fifth, the theory of original intent is inconsistent with most of the Supreme Court's jurisprudence, with the vast majority of scholarly writing, with the opinions of most constitutional historians, and probably with the views of most Americans.

Finally, the adoption of original intent as a universal guiding principle would entail an impossible transition from current constitutional arrangements. As Mr. Bork once put it, " $[t]$ his Nation has grown up in ways that do not comport with the intentions of the people who wrote the Constitution - the commerce clause is one example-and it is simply too late to go back and tear that up. I cite to you the legal tender cases. These are extreme examples admittedly. Scholarship suggests that the Framers intended to prohibit paper money. Any judge who thought today he would go back to the original intent really ought to be accompanied by a guardian rather than be sitting on a bench." 64

\section{ORIGinal Understanding}

With this range of defects it is hardly surprising that Mr. Bork chose to shift his ground somewhat. In The Tempting of America he argues that the understanding of the Constitution's contemporary audience, rather than the intent of its original authors, should determine its meaning. This shift has its disadvantages. The best thing about the intent of the Framers was that it appealed to the intuition that a document must always mean exactly what its authors meant it to. The practitioners of original intent can claim that their method is the one "natural" way to read the text. They can even claim that we often read other legal documents this way - that we try to determine what Congress, or the judge,

63. 98 HARV. L. REV. 885 (1985). For the subsequent controversy see also L. LeVy, ORIGINAL InTENT AND THE FRAMER's Constrrution (1988); Powell, The Modern Misunderstanding of Original Intent, 54 U. CHI. L. REV. 1513 (1987); Berger, "Original Intention" in Historical Perspective, 54 Geo. WASH. L. Rev. 296 (1986); Presser, The Original Misunderstanding: The English, The Americans, And The Dialectic of Federalist Constitutional Jurisprudence, 84 Nw. U.L. REV. 106 (1990).

64. Nomination of Robert H. Bork to be Associate Justice of the Supreme Court of the United States: Hearings Before the Senate Comm. on the Judiciary, 100th Cong., 1st Sess. 84-85 (1987) [hereinafter Hearings]. 
or the administrator meant by a particular word or phrase. Original understanding has less intuitive appeal. Precisely because it is a more sophisticated notion of interpretation, originalism sacrifices the notion that there is only one credible way to read a text. The shift also diminishes the appeal to common experience and the parallel to reading other legal texts.

This problem is a particularly acute one for Mr. Bork. Throughout The Tempting Of America he explicitly connects his struggles to those going on within other disciplines. Most disciplines seem to have rejected the idea that the text can be read to mean only what the author intended. Literary critics and historians have acknowledged other accounts of reading, which abandon author-centricity to focus on context and the text's reception by the reader. These other methods are known generally as "the reader's revolution against the author." They represent everything that Mr. Bork finds most reprehensible in today's scholarship. He quotes approvingly a letter from intellectual historian Gertrude Himmelfarb attacking this openness to other methods of interpretation. "Any methodology becomes permissible (except of course, the traditional one), and any reading of the texts becomes legitimate (except, of course, that of the author)" (p. 137). Professor Himmelfarb's objection would be compatible with a doctrine of original intent. But Mr. Bork's new version of originalism can no longer appeal to the romantic idea that the imperial will of the author must govern the text. "The search is not for a subjective intention" (p. 144). Instead, he lodges interpretive competence in the historically-located readers of the constitution. He has merely shifted ultimate interpretive authority from the Framers of the Constitution to the "public of that time." Mr. Bork has joined the reader's revolution.

As I pointed out before, this switch is a costly one for Mr. Bork. To the initial cost of being seen to adopt the very same methodology criticised by conservatives in other academic disciplines, one has to add the cost of being seen to change from one dogmatically asserted position to another. Mr. Bork obviously feels this one particularly strongly because he denies having done it. Though he described himself during the hearings as "a judge with an original intent philosophy" and argued in print that "original intent is the only legitimate basis for constitutional decision-making," ${ }^{66}$ he says in The Tempting of America that "[n]o even moderately sophisticated originalist" believes the Constitution should be governed by "the subjective intent of the Framers" (p. 218). He suggests that no-one could ever have held such a belief, because it would necessarily mean that the secretly held beliefs of the Framers could change the

65. Hearings, Part 1 at 159 (1987).

66. Bork, supra note 63 , at 823 . 
meaning of the document. Thus all moderately sophisticated originalists must have believed in original understanding all along.

This is a red herring. There are many varieties of intentionalism and many varieties of "reader-controlled" interpretation. But allowing the intention of the author to control interpretation is fairly obviously not the same thing as allowing the understanding of the reader to control. Expanding the definition of intentionalism does not turn it into the philosophy of original understanding. The "intention of the Framers and ratifiers" is not the same as "the understanding of the American people at the time." Mr. Bork seems to find it hard to admit the change.

The most interesting example of Mr. Bork's scholarly method is his use in The Tempting of America of sections of his 1986 article The Constitution, Original Intent, and Economic Rights. ${ }^{67}$ As one might suspect from the title, that article defends original intent. But in The Tempting of America, Mr. Bork uses those sections to defend original understanding. At first glance, it appears that he does this by finding the words "original intent" wherever they appear in the article, and replacing them with "original understanding." Passages in the article originally reproved Paul Brest for failing to understand that the original intent determines the meaning of the fourteenth Amendment. In the book these passages are edited and expanded upon, and a new philosophy of interpretation is inserted. With a quick change of key words they become criticisms of Brest's failure to understand that the meaning of the fourteenth amendment is determined by original understanding.$^{68}$

Even the same counterarguments can be pressed into service. In 1986 for example, he writes that " $[\mathrm{t}]$ here is one objection to intentionalism that is particularly tiresome. Whenever I speak on the subject someone invariably asks: "But why should we be ruled by men long dead?"69 In 1990, Mr. Bork tells us that "[q]uite often, when I speak at a law school on the necessity of adhering to the original understanding, a student will ask, "But why should we be ruled by men who are long dead?" (p. 170). In the era of the word processor, this kind of "search and replace" jurisprudence has its attractions. Still, both the interpretive criteria and the identity of the "dead men" has changed, and Mr. Bork seems uneasy with that fact. 70

The closest Mr. Bork comes to admitting a prior attachment to intentionalism is his confession to having previously "written of the under-

67. Id.

68. Compare id. at 827-828 with The Tempting of America, at 148-9.

69. Id. at 827.

70. Searching for other possible interpretations, I wondered if Mr. Bork thinks original intent and original understanding are the same. In that case, why change his terms and say they are different? If on the other hand, they are not the same, why not admit he has changed his views and explain how he came to believe first that original intent was only permissible judicial philosophy (Id. at 826,832 ) and then that original understanding was the only permissible judicial philosophy? (pp. 9, 146 passim). 
standing of the ratifiers of the Constitution" (p. 144). Actually, he wrote of the intentions of the ratifiers, and a more characteristic statement from his earlier self would be "I wish to demonstrate that original intent is the only legitimate basis for constitutional decision-making." 11 This seems definite enough, but the new Mr. Bork does not like it. Having deemphasised intention, and converted Framers to ratifiers, he then claims that he was merely using "a shorthand formulation, because what the ratifiers understood themselves to be enacting must be taken to be what the public of that time would have understood the words to mean" (p. 144). ${ }^{72}$

\section{Problems With Original Understanding}

So Mr. Bork pays a high price for his move from original intent to original understanding. Is the game worth the candle? Does he succeed in escaping the devastating criticism of original intent which apparently prompted originalists to switch their ground in the first place? Sadly for him, the answer is no. In fact, a little reflection will reveal that the philosophy of original understanding is beset by exactly the same problems as the philosophy of original intent and has less intuitive appeal, to boot. Surprisingly, the implications of the choice between original understanding and original intent have received only occasional attention inside the originalist movement ${ }^{73}$ and little attention outside. ${ }^{74}$

71. Id. at 823 .

72. Of course, according to his new theory, what Mr. Bork meant by his "shorthand terms" is irrelevant, the important thing is what he would be understood to mean when he said "original intent." Perhaps he feels his new method should not apply here. Yet Mr. Bork is stern in pointing out that lawmakers could not use the doctrine of subjective intention to weasel out of something they had said. "If Congress enacted a statute outlawing the sale of automatic rifles and did so in the Senate by a vote of 51 to 49 , no court would overturn a conviction because two Senators in the majority testified that they had really intended only to prohibit the use of such rifles. They said "sale" and "sale" it is. Thus, the common objection to the philosophy of original understandingthat Madison kept his notes of the convention at Philadelphia secret for many years-is off the mark. He knew that what mattered was public understanding, not subjective intentions" (p. 144). One might imagine that the public understanding of "original intent" would be "original intent."

73. The defense of the philosophy of original understanding, that seems to have convinced $\mathrm{Mr}$. Bork is Professor Henry Monaghan's Stare Decisis and Constitutional Adjudication, 88 CoLUM. L. REV. 723 (1988). Professor Monaghan implicitly reproves those who put forward "intentionalist" versions of originalism for providing "an easy mark for critics of originalism." Id. at 725 . His example of an intentionalist who "apparently" holds such as position is R. BERGER, FEDERALISM: The Founders' Design (1987). Id. at n.8. Professor Monaghan is "forced to conclude that original understanding must give way in the face of transformative or longstanding precedent, a conclusion that in turn may make inevitable the unsettling acknowledgement that originalism and stare decisis themselves are but two among several means of maintaining political stability and continuity in society." Id. at 724. This conclusion is markedly more consistent with the Burkean vision of Mr. Bork's views which I present in Section VIII, than with the attempt to "reason without prejudice" towards an abstract and neutral theory of constitutional law. The appearance of Professor Monaghan's article in 1988 may explain the sudden, complete, and unacknowledged reversal of Mr. Bork's opinions about original intent between 1986 and 1990.

74. In fact, a number of those commenting on The Tempting of America do not appear to be aware that Mr. Bork has changed his position from "intent" to "understanding." See e.g., Eric Foner's otherwise excellent review, Bork's notion of framers' 'original intent' smells like big frameup, IN These Times, Feb. 14-20, 1990, at 18. Despite the title of his article, The Original 
The first problem facing original intent was that it could not claim to be the only authoritative way to read a text. Shifting the focus from author's intentions to reader's interpretation lends nothing to the claim to the unique correctness of a method of interpretation.

The second problem facing original intent was the considerable evidence that the Framers themselves intended that their intent should not govern future interpretation. Professor H. Jefferson Powell makes this point in The Original Understanding of Original Intent, ${ }^{75}$ an article cited by every work on orignal intent, with the notable exception of $\mathrm{Mr}$. Bork's. Professor Powell shows that the Framers had a vision of interpretation guided more by the traditional hermeneutic methods of the common law than by the simple notion of original intent. If one had to pick a single motive that prompted originalists to switch their attentions from intent to understanding, it would probably be the difficulty of dealing with this discovery. However, original understanding fares little better among the Framers, as this quotation from Alexander Hamilton might indicate:

The Secretary of State will not deny, that whatever may have been the intention of the framers of a constitution, or of a law, that intention is to be sought for in the instrument itself, according to the usual \& established rules of construction. Nothing is more common than for laws to express and effect, more or less than was intended. If then a power to erect a corporation, in any case, be deducible by fair inference from the whole or any part of the numerous provisions of the constitution of the United States, arguments drawn from extrinsic circumstances, regarding the intention of the convention, must be rejected. ${ }^{76}$

Laws can express or effect more than was intended, or for that matter, understood. In such a case, the true guide is the "usual and established

Misunderstanding, Stephen Presser seems to hold the same opinion. "Judge Bork is a well-known 'intentionalist,' a scholar who believes that it is appropriate and desirable for modern constitutional interpreters to try to understand the aims of those who framed the 1787 document and to implement the framer's intent." Presser, The Original Misunderstanding, 84 Nw. U.L. REv. 106 (1990). Admittedly, as will be seen later, Mr. Bork's position is not always either clear or consistent. He sometimes seems to be assuming that the audience at the time would understand the Constitution to mean what they assumed the Framers intended it to mean, thus merging the two positions. Leaving aside the circular problems of this argument, it is in fact unlikely that a contemporary legally trained reader would have "understood" any such thing. For a definitive and whimsical study of the methodological difficulties involved in both versions of originalism, see Bittker, The Bicentennial of the Jurisprudence of Original Intent, 77 CALIF. L. REV. 235 (1989).

75. 98 HARv. L. REV. 885 (1985). For the subsequent controversy see also L. Levy, ORIGINAI. INTENT AND THE FRAMER's Constrtution (1988); Powell, The Modern Misunderstanding of Original Intent, 54 U. CHI. L. REV. 1513 (1987); Berger, "Original Intention" in Historical Perspective, 54 Geo. Wash. L. Rev. 296 (1986); Presser, The Original Misunderstanding: The English, The Americans, And The Dialectic of Federalist Constitutional Jurisprudence, 84 Nw. L. REV. 106 (1990).

76. Hamilton, Opinion on the Constitutionality of an Act to Establish a Bank (1791) reprinted in 8 Papers of Alexander Hamilton 97-111, at 103 (H. Syrett ed. 1965). 
rules of construction," which at the time certainly did not mean Mr. Bork's theory of original understanding.

The third problem with original intent was its failure as a corrective for indeterminacy. Here too the shift represents no improvement. When one switches from the indeterminate intentions of a group of authors to the indeterminate understandings of an indeterminate group of readers, the problem is hardly solved. The historical methods used to work out the understanding of the public will differ from those used to work out the intention of the framers. Should we follow William Crosskey and develop a "dictionary of the eighteenth century word usages, and political and legal ideas, which are needed for a true understanding of the Constitution"? ?7 Should we parse the Federalist Papers, the hermeneutic conventions of eighteenth century common lawyers, or the propaganda pamphlets and broadsheets which the average voter might have considered? Even if we could agree that understanding rather than intent should govern, how do we decide whose understanding is relevant? Is it that of the delegates to the conventions? The ratifiers? The people who elected the ratifiers? An average member of the legal profession? Of the public? Should we include the disenfranchised, or is this to be an entirely white male original understanding? Even if we could agree on the correct group, the evidence we have of opinions within such groups indicates that their "understanding" diverged markedly depending on class, political affiliation, professional status, and geographical location. ${ }^{78}$

The fourth problem was that in those few cases where we can discern the original intent, it often turns out to be morally objectionable. The same problem afflicts the theory of original understanding. Franchised American society was overwhelmingly a privileged white male group. The opinions of a majority of that group strike us today as sexist, racist, classist, and heavily elitist. Do we want the understanding of these people to govern us?

The final problem with original intent was that it flew in the face of two hundred years of Supreme Court jurisprudence and both scholarly and popular opinion. Again, original understanding fares no better. Like original intent, original understanding is a philosophically flawed, historically unsupported method of interpretation which is often practi-

77. W. CRosskey, Polrtics AND The Constitution IN THE History of The UNITED STATES $1172-73$ (1953).

78. See, e.g., 1 P. Kurland \& R. Lerner, The Founders' Constitution (1987). After promising a 5 volume " 'original understanding' of those who agitated for, proposed, argued over and ultimately voted for or against the Constitution of 1787," id. at xi, the authors had this to say about the determinacy of the their findings. "We are loath to dangle before the reader yet another promise that the crooked will be made straight and the rough places plain; we promise, rather, complexity and complication." In my favorite article on originalism, Boris Bittker quoted the same passage and then, speaking through the mouth of a fictional character, described the founder's intent as "a well stocked pantry waiting for an imaginative chef." Bittker, supra note 74, at 251. 
cally indeterminate, sometimes morally objectionable, and generally at odds with practice and scholarship.

How does Mr. Bork deal with these apparently serious problems? In particular, how does he deal with the very real historical challenges to the validity, workability, and moral acceptability of his method? The Tempting of America offers no answer to these historical objections, and little in the way of history itself. Mr. Bork quotes a few passages from letters or cases, but never engages in the very practice of historical exegesis of the constitution which he would require of judges. The only sustained historical work in the book is a history of Mr. Bork's favorite and least favorite Supreme Court cases. Since his project is to advocate a method based on historical analysis, it may be useful to look closely at the one piece of history he offers.

\section{Mr. BORK's HISTORY}

No one, we presume, supposes that any change in public opinion or feeling ... should induce the court to give to the words of the Constitution a more liberal construction ... than they were intended to bear when the instrument was framed and adopted. . . . If any of its provisions are deemed unjust, there is a mode prescribed in the instrument itself by which it may be amended: but while it remains unaltered, it must be construed now as it was understood at the time of its adoption.

This passage is not taken from The Tempting of America, though it would certainly not be out of place in that book. Nor is it taken from a speech given by a Reagan or Bush appointee to the Justice Department, though it bears all the hallmarks of such a document. The quotation comes, in fact, from a Supreme Court case. Here is a neat and thoroughly authoritative judicial statement of the philosophy of original understanding. As such, one might imagine that it finds great favor with Mr. Bork. Not so. This is a quotation from Dred Scott v. Sandford, ${ }^{79}$ probably the most infamous case ever decided by the Supreme Court and the one most universally reviled by generations of law professors.

This quotation is not an isolated instance. Rather, a large portion of Justice Taney's opinion is given over to the original understanding of the Constitution on the matter of slavery. Justice Taney not only searches for the original understanding of the Constitution, he uses it to interpret the Declaration of Independence. Could the slaveowners who wrote and ratified that document really have intended that "all men" mean all men? Justice Taney uses original understanding to decode the meaning of these apparently general words.

79. Dred Scott v. Sandford, 60 U.S. (19 How.) 393, 426 (1857) (emphasis added). 
The language of the Declaration of Independence is equally conclusive. ... The general words . . would seem to embrace the whole human family, and if they were used in a similar instrument at this day would be so understood. But it is too clear for dispute, that the enslaved African race were not intended to be included, and formed no part of the people who framed and adopted this declaration; for if the language, as understood in that day, would embrace them, the conduct of the distinguished men who framed the Declaration of Independence would have been utterly and flagrantly inconsistent with the principles they asserted; and instead of the sympathy of mankind, to which they so confidently appealed, they would have deserved and received universal rebuke and reprobation. ${ }^{80}$

Some of the Founders of the Republic were slaveowners. So were many of the citizens. Since they cannot be presumed to be hypocrites, and since their understanding of the document-not the meaning that the words have come to acquire-is dispositive, there can be no doubt on the matter. Slaves have no share of the rights claimed by the Declaration of Independence.

Given these methodological premises, how can we doubt that Dred Scott will lose? Changing sentiment or moral outrage are irrelevant. Here is the unedited version of the quotation:

No one, we presume, supposes that any change in public opinion or feeling, in relation to this unfortunate race, in the civilized nations of Europe or in this country, should induce the court to give to the words of the Constitution a more liberal construction in their favor than they were intended to bear when the instrument was framed and adopted. ${ }^{81}$

Justice Taney, like Mr. Bork, knows that his conception of the judicial role is the correct one. Justice Taney, like Mr. Bork, has in his hands a timeless document.

It is not only the same in words, but the same in meaning, and delegates the same powers to the Government, and reserves and secures the same rights and privileges to the citizen; and as long as it continues to exist in its present form, it speaks not only in the same words, but with the same meaning and intent with which it spoke when it came from the hands of its framers, and was voted on and adopted by the people of the United States. Any other rule of construction would abrogate the judicial character of this court, and make it the mere reflex of the popular opinion or passion of the day. This court was not created by the Constitution for such purposes. Higher and graver trusts have been confided to it, and it must not falter from the

80. Id. at $409-10$

81. Id. at 426 . 
path of duty. ${ }^{82}$

Does Dred Scott discredit the philosophy of original understanding? Obviously, it is disconcerting to find one's philosophy serving as the cornerstone of the most reviled case in the history of the United States Supreme Court. It is more than disconcerting to find that original understanding seems to write Blacks out of the Constitution and the Declaration of Independence. Still, one might argue that even a good method can produce bad results. Is that Mr. Bork's response? Not exactly.

Mr. Bork does feature Dred Scott in his capsule history of the Court. He also agrees that the case is a bad one--"[s]peaking only of the constitutional legitimacy of the decision, and not of its morality, this case remained unchallenged as the worst in our history until the twentieth century provided rivals for that title" (p. 28). How does Mr. Bork deals with this taint on the escutcheon of original understanding? Well, by ignoring it, mostly.

The case takes up 241 pages in the Reports. There is no need to examine all of its dubious arguments; it was quite evident not only that Scott was to remain a slave but that Justice Taney intended to read into the Constitution the legality of slavery forever" (p. 30).

Having decided that there is "no need to examine" Justice Taney's "dubious arguments," many of which were appeals to original understanding, Mr. Bork concludes that the real evil in Taney's opinion is that it introduces the concept of substantive due process. He describes this concept as one "that has been used countless times since by judges who want to write their personal beliefs into a document that, most inconveniently, does not contain those beliefs" (p. 31). With this breathtakingly simple move, Mr. Bork himself is able to ignore the inconvenient parts of Taney's opinion, to concentrate solely on Taney's "introduction" of substantive due process. Mr. Bork considers substantive due process one of the most appalling features of contemporary liberal jurisprudence. The message is clear. This is "the worst constitutional decision of the nineteenth century" (p. 28), and it is the ancestor of contemporary liberal constitutional interpretation. Can the fruit fall far from the tree?

As if this were not enough, Mr. Bork then turns round and concludes that the judicial hero of Dred Scott, Justice Benjamin Curtis, author of the dissent, was the real proponent of originalism in this case. He achieves this by using quotations from the dissent which will not bear the meaning he assigns them, while ignoring the explicit defense of original understanding in the majority opinion. From Mr. Bork such scholarship is more disappointing than it would be from most scholars. Mr. Bork's constitutional philosophy relies on the historical record as a check against

82. Id. 
judicial activism. Yet, with "history" like this, what could not be proved? Let us be charitable and assume that he did not have the opportunity to read the case before writing about it. How might he deal with what Taney's opinion really says?

Mr. Bork could account for the majority opinion in Dred Scott in one of two ways. First, he could say that his method can be convincingly manipulated to reach bad results. This response, however, tends to undermine his claim that reliance on original understanding constrains judicial behavior. Second, he might say that the method was correctly used but that it produces repugnant results in this case because the Framers and ratifiers of the Constitution were racists. This raises the more fundamental question of morality. Taney argues with some force that the historical record shows that, at the time of the writing of the Constitution, the "unfortunate" Negro race was thought of as almost a different species. This view, to say nothing of views about women or the working class, are part of both the intention of the Framers and the understanding of franchised citizens at the time. Can we accept as an interpretive guide to the Constitution the understanding of a group of men whose views were sometimes so abhorrent? Mr. Bork might try to answer these objections by pointing out that there were also abolitionists and radical republicans at the Philadelphia Convention, among the ratifiers of the Constitution, and scattered through the general voting population. But that observation undermines the notion of a single "original understanding."

Mr. Bork's actual response seems to be that the morally abhorrent views of the Framers have since been purged from the Constitution by the fourteenth and nineteenth amendments. This is a particularly weak argument, in a book not unduly burdened by strong ones. Imagine for a moment that Mr. Bork can identify some coherent group whose understanding of the Constitution is clear and consistent and whose views ought to bind us. Does he think that the moral views of that group were not part of a system but rather a random collection of separate, independent elements? Can we discard racism and misogyny, keeping the rest intact? If you believed women, Blacks and the working class to be inferior and fundamentally untrustworthy, your ideas about the necessary structure of society and the division of powers between the organs of government would obviously be different from those of someone working from more egalitarian and democratic assumptions. It is a strange world Mr. Bork lives in, if he thinks a person's deepest moral views have no connection to each other, no implications for their other ideas. But then again, Mr. Bork does live in a strange world. His unusual combination of authoritarian constitutional interpretation and moral skepticism probably does allow him to believe that moral values have no connection to each other. 
The liberal response to the problem of eighteenth-century bigotry is to say that we should not be faithful to the Framers' intentions, or to the understanding of those who ratified the Constitution, but instead to a generalized and coherent version of the moral system they articulated. When the authors of the Declaration of Independence say "all men," meaning and being understood to mean only white men, we should abstract the universal principle from its rough and irrationally biased historical origins. Purified in the fires of Kantian moral theory it will give us the non-racial, sexually equal democracy we (in the insidious knowledge class) have always wanted. This answer will not save Mr. Bork's project. In fact, it is what he fears most. ${ }^{83}$

Having examined every possible avenue of escape for Mr. Bork, we can see why he finds "no need" to trace out Taney's "dubious arguments." Those arguments are his own, and they lead him where he does not want to go.

\section{Is BORK A BURKEAN?}

At the beginning of this essay, $I$ argued that it would be a mistake to dismiss Mr. Bork's work too easily. It is true that its philosophical and historical errors, confused argumentation and sloppy research ${ }^{84}$ make it a particularly easy target for the reviewer's barbs. Nevertheless, to dismiss it with a facile (or even a contemptuously patronizing) account of its manifold contradictions is to leave a number of important questions unanswered. If the arguments in this book are really so weak, why does one get the sense while reading it that it taps some deep wellspring of discontent with the discourse of liberal politics and academia? Put another way, if this book-praised to the heavens by the conservative political pundits featured on the book jacket-seems to liberals to be just so much dross and bluster, is one side being deceitful, or is there is a fundamental breakdown of communication between the two sides?

I would like to suggest that The Tempting of America is, in fact, a schizophrenic work. On one hand, it attempts to justify the theory of

83. Mr. Bork explicitly rejects such a process. "The role of a judge committed to the philosophy of original understanding is not to 'choose a level of abstraction.' Rather it is to find the meaning of the text-a process which includes finding its degree of generality which is part of its meaning. .." (p. 149). That meaning, of course, can only come from text and original understanding, not from Kantian moral theory. Mr. Bork has been strongly criticized by liberal legal theorists, particularly by Ronald Dworkin, for his failure to "purify" the original understanding by raising it to a higher level of generality. Ironically, the method Dworkin espouses is exactly the method Mr. Bork himself advocated in his writings in the late sixties and early seventies, though Kant seems to have whispered different results into their respective ears.

84. Sloppy research seems the most charitable explanation for Mr. Bork's treatment of Dred Scott. Other parts of the book show that the pressure of timely publication may have worked its subtle magic on Mr. Bork's table of authorities. Admittedly, the relatively indiscriminate citation which results has its own charming compensations. Senator Edward Kennedy and Professor Duncan Kennedy will no doubt both be dismayed to find that the index has amalgamated them into a single person with an impressive, if varied, list of publications (p. 412). 
original understanding within the epistemological framework of liberal rationalism, while on the other it presents a basic challenge to that entire framework. To be sure, the challenge is not a systematic one. To be sure, it was made (and made better) over two hundred years ago by Edmund Burke. To be sure, Mr. Bork does not himself distinguish the occasions on which he is working within the canon of liberal thought from the occasions when he is challenging it. But there is a challenge here, nonetheless: a challenge to such foundations of liberal rationalism as the idea that no one has a privileged insight into the moral universe, or that the only social institutions worth keeping are those which pass test of reason. In fact, there is a challenge to the possibility of comprehending the social world at all through the reliance on only "the fallible and feeble contrivances of our reason." 85

Seen in this light, this book may mark a departure for Mr. Bork. For the first time, he seems to question the centrality of the problem of value, the problem which has animated all of his previous conservative incarnations. Each of the theories he has espoused promised to solve, or at least salve, the problem that, in a liberal society, values are presumed to be subjective and arbitrary and the state is supposed to embody no particular conception of the good. Some of the theories offered a neutral method (economic analysis, neutral principles), while others claimed to have identified the right parties whose values should govern (libertarianism, process theory, and original intent). All assume that the subjectivity of values is the problem to be solved and that reason is the tool to solve it. It is my claim that, at certain places in his most recent work, Mr. Bork moves away from both of those assumptions. To explain how he does so, I must first set the stage.

So far in this article I have concentrated on those places where Mr. Bork has tried and failed to fit his ideas into the analytical framework provided by liberal rationalism. In this section I will focus on the other strand of his ideas. In order to do so, I will compare Mr. Bork's ideas to those of those of the great 18th century conservative, Edmund Burke. Burke wrote at the dawn of "the age of reason," while Bork writes in what is supposed to be its twilight. The surprising similarities in their ideas may explain the attractiveness of Mr. Bork's work despite its analytical flaws. At the same time, it may illuminate the condition of late twentieth century conservative thought. To bring out this other side of Mr. Bork's work, it is necessary to return to those parts of his argument which seem most dogmatic and contradictory-in particular, his attempt to have his philosophy of interpretation imposed as a prerequisite to judicial confirmation, and his account of the legitimacy of "moral legislation."

85. E. Burke, Reflections on the Revolution in France 121 (C.C. O'Brien ed. 1968). 
Mr. Bork believes that to require judicial candidates to adhere to one interpretive method would be a contentious, political, and therefore a bad decision. We could not insist, for example, that candidates for the Supreme Court promise to consider only the face value of the words of the Constitution. Nor could we insist that judges swear that they would interpret the Constitution's provisions in the light of changing moral sentiment, economic efficiency, technological progress, or democratic values. To impose any of these interpretive methods would be "political." But he does not consider it "political" to insist, as a precondition for their confirmation, that judges swear loyalty to the method of original intent. It is not political, it seems, because that method is right.

This confident willingness to dictate a method to those with different views is hard to reconcile with relativism and the idea that values are subjective. After all, one premise of the liberal state is that no one has a privileged insight into the moral or philosophical universe. ${ }^{86}$ No one can use a claim to moral truth to get the state to enforce his views on others. $^{87}$

Mr. Bork's attempt to justify his dogmatism within the strictures of liberal rationalism results in the knotty difficulties described in the first part of this essay. He claims that his current method of interpretation is not one among competing methods, but is instead the only way to read a legal text properly. He claims that it is neutral in derivation and application, and not a set of value judgements. If value judgements are being imposed, they are those of the Framers and ratifiers. He claims that his method is well-founded historically, and that we would have to invent it if it were not. He claims so many things, and so unconvincingly, that one is driven to wonder if he cares about this side of his argument. These difficulties would all disappear if Mr. Bork decided explicitly to reject the premises of liberalism. It would be stretching the point to say that $\mathrm{Mr}$. Bork does in fact make a frontal attack on these premises. But for every time that he accepts them, there is another moment when he challenges them. His discussion of morals provides a particularly good example.

At first, Mr. Bork comes across as entirely conventional in his premises, if not his conclusions, about moral argument. Like the sexually

86. Hence liberals argue that decisions about value should be solved by the aggregation of individual subjective choices. The democracy adds up our individual subjective values as expressed by votes, and the market adds up our individual subjective values as expressed by the dollars we spend. Mr. Bork appeals powerfully to this tradition when he claims that the effect of knowledge class's attack on original intent has been to take value judgements away from the legislatures. After all, questions on which reasonable people can disagree should properly be decided by democratically elected representatives, because judges do not have a superior insight into the moral or philosophical universe. Unelected judges should not impose their subjective views on others. Yet, to get to this point, he must argue that originalism is both correct and a-political. Surely this implies that some (unelected) people, Mr. Bork among them, do have a superior insight into the philosophical universe-and are not at all chary about imposing their correct insight on others.

87. This, of course, is exactly Mr. Bork's criticism of the liberal jurisprudes and judges. 
active, egalitarian members of the knowledge class, Mr. Bork often sounds like a social rationalist and a moral relativist. Scattered throughout The Tempting of America are discussions apparently based on the idea that moral values (but not interpretive methods) are subjective, relative, and not subject to rational discussion. It is for exactly this reason that he believes that some of the issues beloved of liberal constitutionalists should be decided by legislatures rather than courts. Courts have no business deciding questions of value, where one person's opinion is as good as another's. In these cases the majority decision is the only valid one.

This opinion recurs frequently, as, for example, in his discussion of the death penalty. He says of that debate, for example, "[i]t does no good to dress the issue up as one of moral philosophy, because such philosophy does not give a clear answer. Arguments have been made both ways and none is conclusive" (p. 214). Mr. Bork does not think much of contemporary academic forays into moral philosophy. He points out that "[i]f the greatest minds in our culture have not succeeded in devising a moral system to which all intellectually honest persons must subscribe, it seems doubtful, to say the least, that some law professor will make the breakthrough any time soon" (p. 255). Who can disagree? He announces that he has made a decision, already evidenced by his presentation of opposing arguments, to give up reading legal scholarship of this type. "There comes a time to stop visiting inventor's garages to see if someone really has created a perpetual motion machine" (p. 255). Who can fail to sympathize? Mr. Bork even agrees with Alisdair MacIntyre that "[t]here seems to be no rational way of securing moral agreement in our culture."88 Again, these seem like the words of a moral relativist.

In his argument for "legislated morality," however, Bork's views become more complicated. He still seems to believe that moral decisions are not subject to proof or refutation and therefore are unreviewable by the analytic techniques of judicial reason. Thus they must be left to the democratic legislature and the majority view. Although this certainly seems like moral relativism, Mr. Bork reserves the term "relativist" for those who disagree with him about the propriety of "legislated morality."

Liberals assume that if morals are subjective and relative, the state should not be allowed to legislate morality for its citizens. Mr. Bork draws rather different conclusions.

There being nothing in the Constitution prohibiting legislated morality, the only opposition to it rests upon a moral view. The Bowers dissent said as much when it stated as a "moral fact" that a person belongs to himself and not to others or to society. Moral relativism is, after all, one moral position. But the imposition of

88. A. MAcintyre, After Virtue 6 (2d ed. 1984), quoted in Bork at 256. 
moral relativism upon legislatures by judges is not, strictly speaking, moral relativism in itself. It is more accurately described as the belief that the only valid and trustworthy morality is the judges'. (p. 126)

The key to this argument is the way it deprives moral relativism of universal status. By characterizing relativism as just one particular moral system, rather than as universal claim about all moral systems, Mr. Bork is able to turn the tables rather neatly. To say that we cannot legislate morality would be to impose a moral view-moral relativism-something which moral relativism itself should prohibit. Legislated morality cannot be reviewed, precisely because it is morality. The judge's opinion is of no more weight than anyone else's. Very well, then. How do we know when something is a moral issue? The answer to that question turns out to be a little more complicated.

Discussing the application of the fourteenth amendment's guarantee of equal protection to laws which make distinctions on the basis of gender or sexual orientation, Mr. Bork makes two interesting pronouncements. The first is about gender. "The general language of the clause, however, continues to subject such cases to the test of whether statutory distinctions are reasonable. Sexual differences obviously make some distinctions reasonable while others have no apparent basis" (p. 150). Now, it might appear unreasonable to ban homosexuals from military service without proof that letting them serve would have negative effects. It might appear unreasonable to criminalize a particular sexual practice between consenting adults in their own home simply because some people don't like the idea of it. Mr. Bork does not find it so. "Society's treatment of sexual orientation is based upon moral perceptions, so that it would be difficult to say that the various moral balances struck are unreasonable" (p. 150, emphasis added).

The boundaries shift in this argument. Disparate treatment of women can only be allowed if the distinction is reasonably based on (presumably physical) sexual differences. Mere opinion or prejudice is not enough. Disparate treatment of gays, however, is "based on moral perceptions" and therefore "it would be difficult to say" that they were "unreasonable." He restates this theme in more uncompromising tones in his discussion of Bowers v. Hardwick. ${ }^{89}$ "[T] he suit was surely brought to seek a declaration that would equate the constitutionality, and hence the presumed morality, of homosexual and heterosexual conduct. Hardwick's suit, in a word, rested upon nothing in the Constitution and so was one more sortie in our cultural war" (p. 117).

How does Mr. Bork know that discrimination against gays is a matter of unreviewable and a-rational morality, while any discrimination against

89. 478 U.S. 186. 
women must undergo judicial scrutiny for reasonableness? Those who believe that a woman's place is in the home argue that any other state of affairs is unnatural and immoral. How does Mr. Bork determine what constitutes a legitimately moral issue as opposed to merely an irrational prejudice? The answer, I think, is that an issue is a "moral" one if it has been traditionally seen as one by the majority of people in the society. I can see no other distinction which will allow Mr. Bork to call discrimination against gays, but not against women, a matter of "morality."90

Mr. Bork's constitutional philosophy is not as changeless and neutral as he pretends. He rails against liberals for modifying the constitution according to changing moral sentiments, yet his interpretive method will produce different results when sentiments change about which issues count as moral ones. Mr. Bork appears as blind to this contradiction as he was to the one between his complaint about the political litmus test applied in his confirmation hearings and his own advocacy of such a test.

These contradictions lead us back to the possible challenge to Enlightenment premises hinted at in Bork's theory. I started this section pointing out that Mr. Bork often strays far from the two core premises of postEnlightenment liberal thought about social institutions. The first premise is that social institutions should be held up to the test of reason, and those that cannot be rationally justified should perish. The second is that morals are subjective and relative and not subject to rational proof. ${ }^{91}$ From the second premise, or sometimes from the conjunction of both premises, we derive this corollary: since no one has a privileged insight into the moral universe, the state should be neutral among conceptions of the good. In his discussion of sex discrimination, homosexuality, moral legislation, and judicial method, Mr. Bork oscillates between criticizing and relying on these liberal premises. He talks like a relativist one moment, and then like one possessed of The Truth. He criticizes liberals for imposing their ideas of judicial method and then argues that his own should be imposed. He takes the liberal premise about relative values and draws from it the conclusion that the judges cannot force the state to be neutral among conceptions of the good, because that would be the

90. And even there, I suspect he might be wrong given the traditional "moral" justifications of sexism.

91. The contradiction between these two premises frames the most common source of critiques of liberalism. For two very different such critiques see R. UnGER, KNOWLEDGE AND Politics (1975) ("The characteristic predicament of the modern lawyer is to argue constantly about policy, as if rational choice among competing values were possible, yet to remain faithful to the idea that values are subjective and to the political doctrine of which that idea is a part.") and Arrow's Impossibility Theorem (There are four minimum, but mutually exclusive, conditions which would have to be satisfied for social choice accurately to reflect popular preferences. Social choices would have to be transitive, free, and based on "endogenous" preferences. It must also be free from an inverse relationship between the popularity of a choice and society's tolerance of it. According to Arrow, all four conditions cannot be satisfied at once.) For problems in the conceptualization of "choice" in models relying on an Arrovian vision see Kelman, Choice and Utility, 1979 WIS. L. REV. 769; A Guide to Critical Legal Theory (1987). 
imposition of a particular conception of the good. He tells judges that they should wear their critical rationalist hats in reviewing laws which burden women, but their deferential relativist hats when they are reviewing laws burdening homosexuals.

Mr. Bork is at his strongest in his fragmentary critiques ${ }^{92}$ of rationalism and relativism, so it is these that I propose to develop. I do so partly because I am aware of the place of such a critique in the heritage of conservative thought. There is a noble tradition of conservative attacks on rationalism, relativism, and the other bulwarks of liberalism. Edmund Burke mounted exactly such an attack. Burke's scattered topical writings resist summary, but his fundamental criticism was of the hubris involved in supposedly rational criticisms of social institutions. Scornful of the dogma that all values are relative, Burke argued that all worthwhile values come from the often unreflective acceptance of a society's traditions. The most telling theme of Burke's writings is his defense of this unreflective acceptance, which he defiantly called "prejudice," against the illusion of reason.

Burke argued against the rational reform of social institutions by pointing out that the human ability to foresee was finite, whereas the tests to which existing social institutions were subjected were infinite. We should not abandon an institution simply because it is susceptible to rational criticism. Despite a lack of ostensible justification, an institution might now be fulfilling social functions of which we are ignorant. Puffed up with pride in the power of reason, we might fiddle with something vital to the structure of our society. Instead, we should put our trust in tradition and "nature." Or, as Burke would put it, "by calling in the aid of [nature's] unerring and powerful instincts, to fortify the fallible and feeble contrivances of our reason, we have derived several other, and those no small benefits from considering our liberties in the light of an inheritance."93 Thus, traditions which seem contradictory, chaotic, and irrational should be embraced and defended against the facile wisdom of those who "[b]y what they call reasoning without prejudice ... leave not one stone upon another in the fabric of human society. They subvert all the authority which they hold as well as all that which they have destroyed."

This is fine strong stuff. Contemptuous of liberal paeans on the power of reason, Burke puts his faith in tradition, prejudice, and solid quiet opinion. Such a theory could support the imposition of oaths to follow

92. I say fragmentary because it would be unfair to call Mr. Bork a systematic thinker. He seems uncomfortable with abstractions. This is not necessarily a criticism. In fact, it is the strength of many of his most interesting arguments. For example, he prefers to argue for moral relativism on the basis of the number of people who have tried and failed to build an objective moral theory, than to argue that the fact/norm dichotomy makes it conceptually impossible. In this, he is very like Burke.

93. BURKE, supra note 85 . 
one kind of judicial interpretation-provided only that it be proved to be traditional. Indeed, such a theory could support the imposition of more overt conservative oaths to defend the status quo, should that be necessary. Is Mr. Bork a Burkean? Should he be one?

At first sight, the answer to both questions is "no." After all, Mr. Bork claims that his constitutional philosophy is objectively correct, that it is neutral in derivation and application, and that it does not represent the imposition of a particular set of values onto the Constitutional document. This sounds like the sort of attempt to "reason without prejudice" about social institutions of which Burke was so contemptuous. Yet, as we have seen, Mr. Bork's arguments for the objective correctness of the theory of original understanding are philosophically bankrupt, historically unfounded, and practically indeterminate. His account would be more persuasive if he were to abandon the claims to objective correctness.

Probably the greatest structural similarity between the ideas of Burke and Mr. Bork, is their resort to a kind of class analysis. Each sees himself as the defender of a strong but inarticulate tradition against the depredations of an intellectual class drunk on its own wordy theories. ${ }^{94}$ Burke's opponent was the reformism, iconoclasm, egalitarianism, and dangerous rationalism of the parvenu bourgeoisie. He set himself up against "the delusive plausibilities of moral politicians,"95 saving his sharpest barbs for what he saw as their mindless love of change for change's sake. "A spirit of innovation is generally the result of a selfish temper and confined views. People will not look forward to posterity, who never looked back to their ancestors."96 Burke argued for the spontaneous, organic and above all traditional process of government, a process which was valuable regardless of whether it was explicable in terms of the new categories of the rationalists. "All your sophisters cannot produce any thing better adapted to preserve a rational and manly freedom than the course we have pursued, who have chosen our nature rather than our speculations, our breasts rather than our inventions, for the great conservatories and magazines of our rights and privileges." 97

Mr. Bork's villains are the intellectual or knowledge class, but the opinions that class possesses are exactly the proud, questioning and

94. "Intellectual presumption-or self-confidence-is the morale of the revolutionary, whereby he is enabled to call established order into question, in society, in the State, in the Church, in the family. This is the way in which ability makes its inroads into property. In using his magnificent intelligence to deprecate the claims of intelligence, Burke as usual, is discharging a double function. He serves the interests of the property owners, thus earning their gratitude. And at the same time he rehabilitates religion, and notably-though discreetly and by indirection-that form of religion which had most been exposed to the remorseless onslaughts of Reason." C.C. O'Brien, Introduction, id. at 47.

95. Burke, supra note 85 , at 125 .

96. Id. at 119 .

97. Id. at 121 . 
rationalist ones that Burke criticized. This is not surprising when one realizes that it was Burke's parvenu eighteenth century bourgeoisie who developed the ideology that Bork's knowledge class now expounds. Not only are the ideas of the knowledge class marked by the hubris of rational social reform, they are constantly in flux. Sounding a common note with Justice Taney, Mr. Bork decries the idea that changing sentiments could have any effect on constitutional law. "The assumptions and ideas of the intellectual class regularly mutate, which means, to the extent that constitutional law incorporates these assumptions, our fundamental law will shift with fashion" (p. 242). Burke made the same point about the social reformers of his day, using the same comparison with fashion.

Not only the traditions of governance, but moral traditions also need to be defended against the knowledge class's rationalistic tinkering. Like Burke, Mr. Bork is at his most emphatic when he extols these values. He argues specifically against the liberal vision of the morally neutral state. For him society must be able to legislate its moral values if it is not to "dissolve social bonds" (p. 249). He quotes approvingly Lord Devlin's dictum: "[w]hat makes a society is a community of ideas, not political ideas alone but also ideas about the way its members should govern their lives" (p. 249). Burke would have applauded. The liberal tradition sees civil society as an empty vessel to be filled with, rather than to shape or determine, the values and preferences of its citizens. It is precisely this relativist attitude which gives the state its universal status above any of the particular groups, parties, or religions which it contains. Burke considered this idea of a neutral universal state a delusion. There could be no state, no justice, even no understanding, outside of a particular tradition of governance, law, religion, culture and language. The crux of traditions is that they are not "rational." We should protect the social fabric of our society, from its great institutions of government to its smallest traditions of personal morals and etiquette, from the rationalist assault.

In liberal thought, society is a container full of independent actors with different desires and values. Values and desires may change, just as different drinks can be put into the same glass, but the society remains. On the other hand, writing in the tradition of classical republicanism, Burke and Mr. Bork see each society as an expression of a particular set of traditional values and assumptions. To destroy those assumptions is to destroy the society. In fact, the possibility of change in social attitudes represents such a threat to Mr. Bork that he might support the use of state force to prevent it. "A change in moral environment-in social attitudes towards sex, marriage, duties towards children and the likemay surely be felt to be as harmful as the possibility of physical violence or the absence of proportional representation of ethnic groups in the 
workforce" (p. 247). If we can use the power of the state to prevent the latter two evils, why not the former? Of course, this represents a profound contrast with Mr. Bork's earlier views. The current Mr. Bork has abandoned the libertarian concerns which led him to criticize moral legislation. He seems to have deserted the liberal world where values may not be legislated, for the Burkean world where they must be.

Both Burke and Mr. Bork are most effective when they point out the contradictions in liberal thought. Mr. Bork points out that liberals want it both ways - to impose their ends-neutral vision of the state, and then to claim that this vision is not a political or moral vision at all. Score one for Mr. Bork. He asks how liberals can trumpet their relativistic vision while at the same time imposing on the country their moral views on such issues as busing, school prayer, and the "prohibition of father-son banquets at high-schools." "On the one hand, there appears to be a degree of morality so severe it amounts to moralism, and, on the other, a hostility to morality so strong it amounts to moral relativism" (p. 245).

Writing at the beginning of the rise of liberalism and the dawn of the political Enlightenment, Burke had a similar disdain for the way that the liberal exaltation of "toleration" played itself out in state policy. "We hear these new teachers continually boasting of their spirit of toleration. That those persons should tolerate all opinions, who think none to be of estimation, is a matter of small merit. Equal neglect is not impartial kindness." $98 \mathrm{He}$ was particularly incensed at the suggestion of Reverend Price that those who did not find the Church of England congenial should set up their own religion.

It is somewhat remarkable that the reverend divine should be so earnest for setting up new churches, and so perfectly indifferent concerning the doctrine which may be taught in them. His zeal is of a curious kind. It is not for the diffusion of truth, but for the spreading of contradiction. Let the noble teachers but dissent, it is no matter from whom or from what. This great point once secured it is taken for granted that their religion will be rational and manly. ${ }^{99}$

It might be Mr. Bork speaking, taxing liberals for exalting the values of homosexuals, criminals, and drug users in the name of tolerance and moral relativism, while they denigrate the values of the moral majority.

The cause of this double standard is the knowledge class's pernicious egalitarian ethos (p. 245). Both Burke and Bork think that egalitarianism is a corrosive doctrine, weakening the social distinctions and mental habits on which social stability is founded. Burke called it "that monstrous fiction, which by inspiring false ideas and vain expectations into men destined to travel in the obscure walk of laborious life, serves only to

98. Id. at 258-59.

99. Id. at 95 . 
aggravate and embitter that real inequality which it never can remove; and which the order of civil life establishes as much for the benefit of those whom it must leave in an humble state, as those whom it is able to exalt to a condition more splendid, but not more happy." ${ }^{100}$ Mr. Bork is as dismissive, if less florid. "Egalitarianism is hostile to hierarchies and distinctions. Hence law must be used to weaken or eliminate them, striking at private morality and behavior that is not egalitarian. For entirely innocent reasons, the preferences and talents of people will not always produce equality of results. The egalitarian tendency is then to coerce equality of result by law" (p. 245-6). The best protector of these "entirely innocent inequalities" is the unquestioning reverence of traditional values which both Burke and Mr. Bork extol.

A desire to defend society from the "delusive plausibilities of moral politicians," a condemnation of the hubris of rational reformism, a hostility to the epistemology of moral relativism and the liberal vision of a morally neutral state, an exaltation of tradition against the demands of egalitarian social thought-all of these unite Burke and Mr. Bork. In fact, all that divides them is Mr. Bork's lingering but tenuous attachment to the language of rationalism, the language favored by many of his foes in the knowledge class.

The language of liberal rationalism conjures up a world where social realities are objectively knowable facts, while values are relative, subjective and partial. If one accepts these premises, then the epistemological task is to jump this gap, to reach objective knowledge of the Good, or in this case, of the Constitution. Various methods are suggested. But whether the method entails a veil of ignorance or an ideal speech situation, wide reflective equilibrium or participation-reinforcing process theory, it has a single goal: to achieve a kind of knowledge free from prejudice and partiality, which does not equate "that which is" and "that which should be," and which does not have a particular set of values built into its methodological premises. These goals are the very ones that part of Bork holds dear. He spends half of his time arguing that his method gives us access to facts and not values, that it is neutral in derivation and application, and free from prejudice and partiality. He spends the other half of his time arguing, in the good Burkean manner, in favor of prejudice and partiality, in favor of the authority of tradition, and in favor of a state which is not neutral as to moral values, but instead writes one particular set of values into law. Mr. Bork seems to imagine that the contradiction is simply between that which the Constitution proscribes and that which the majority is entitled to do. But it is more than that. It is a fundamental clash of ideologies, of epistemologies, of political visions. It is the reappearance of this clash within his theory of

100. Id. at 124 . 
originalism that marks the failure of his project. After all, if the conservative republican vision of the state is correct, what is wrong with a politically "prejudiced" theory of interpretation and constitutional values? A modern-day Burke would say that, since all understanding must start from the values of a particular tradition and a particular social order, there can be no other kind. ${ }^{101}$ On the other hand, if the conservative vision is wrong, there is no foundation for Bork's reliance on tradition, his attack on the moral relativism of the knowledge class, or his panegyric upon a state which "must legislate moral values if it is not to dissolve social bonds." He simply cannot have it both ways. He should give up his lip service to the liberal conventions of argument.

My point here is that Mr. Bork has tried to hold together a fundamentally schizophrenic argument. He has struggled to fit the ideas of traditional conservatism within the framework of liberalism. The lacunae and contradictions in his book thus represent not simply mistakes, but rather signs of a deep epistemological tension. What would happen if he simply jettisoned the liberal rationalist side of his ideas? He would have to abandon his claim that his theory of interpretation is neutral in derivation and application. He would have to embrace as the final legitimator of his theory not the "fallible and feeble contrivances of reason," but instead "prejudice" and tradition. Such an admission would encourage readers to focus their attention on the profound challenge which this kind of conservatism represents for the epistemology of liberal rationalism.

What kind of constitutional philosophy would this produce? It would start from premises rather different from those of liberalism. The assumption would be that legitimacy could adhere only to the content of particular social orders, rather than to some general plan of ordered liberty. Thus, in constitutional decision-making and scholarship, there would be less resort to the abstract reasoning that so infuriates Burke and Mr. Bork, and more reliance on the values and traditions of this particular society. Liberal analysis purports to start from a place outside any particular clash of values. Will the Nazis get to march through Skokie, or can the residents prevent them? Can 2 Live Crew play uncensored in Florida, or can the local authorities stop them? To resolve these clashes, liberalism interprets the Constitution as a set of universal norms which stand on a higher level than any particular clash. It can thus can be

101. Mr. Bork has two contradictory responses to this point: one from his liberal side, the other from his Burkean side. His first response is to deny that the adoption of his theory is a political choice or that his theory embodies a particular set of values. In an echo of his bygone Wechslerian days, he argues that his theory is neutral in derivation and application. His second response is that the adoption of original understanding is a political choice, but that it was a choice "made long ago by those who designed and enacted the Constitution" (p. 177). It does embody a particular set of values, but they are the values of the Framers (and enactors). The former argument suffers from the philosophical flaws pointed out in section VI. The latter, notwithstanding its perfect circularity, is undermined by the problems of history discussed in the text accompanying notes 60-66. Finally, of course, both arguments cannot be true at the same time. 
enforced without violating the injunction that the state should embody no particular set of political beliefs. ${ }^{102}$ Liberalism casts itself as the umpire in a clash of ideologies, not as one of the players, not as an ideology itself.

To Mr. Bork, however, it is clear that the norms enforced do in fact reflect a particular set of political beliefs-those of Professor Tribe and the knowledge class - and no argument that these norms are immanent in the constitutional order will convince him. A Burkean constitutional theory would claim that there are no universal norms of process which allow us to solve a dispute without, ourselves, entering into the fray. Instead, we must accept that the state itself embodies a particular set of value judgements and that realization of these values is a good thing. Rather than hanging above the clash of ideologies, the state actively promotes a particular path of virtue. This would be a constitutionalism based on societal traditions, skeptical of claims to universal truth.

This Burkean theory of constitutional law would in some ways resemble recent "republican constitutional theory." 103 From its inception, the liberal refrain in American politics and constitutionalism has had a contrapuntal theme of republicanism. So far, the majority of republican constitutional scholarship has taken the republican injunction to civic virtue to refer to the "active" virtues of political action and civic participation in the life of the republic. A Burkean republicanism would be more concerned with the passive virtues, such as acceptance of one's place in the hierarchy and conformity to the traditional moral norms of society. Nevertheless, it would share with its radical republican counterpart a belief that the state cannot be a mere empty vessel, containing the values of its citizens but not partaking of them.

For the liberal, the state is just a means to an end, a device to maximize individual freedom. For the Burkean, the state is an end in itself. This difference has radical implications for the question of state interference with individual interests. Both "freedom" and "state" take on a particular meaning, in the Burkean's case a traditional one.

[W] hile the conservative may require a loose connection between the state and civil society (looser, say, than that which exists in China), he will wish to see the state as end and not as means, just as he sees civil society. The state as means (as administrative machine, or business enterprise or welfare officer, or whatever) - such a state is

102. The best chroniclers of this aspect of the aspirations of the liberal state are, ironically enough, Marx and Hegel.

103. See generally Roads Not Taken: Undercurrents of Republican Thinking in Modern Constitutional Theory, 85 Nw. U.L. REV. 1 (1990); Horwitz, Republicanism and Liberalism in American Constitutional Thought, 29 WM. \& MARY L. Rev. 57 (1987); J. Pocock, ThE Machiavellian Moment: Florentine Political Thought and the Atlantic RePUblican Tradirion (1975); Sunstein, Beyond the Republican Revival, 97 Yale L.J. 1539 (1988). 
not one to which the citizen can belong. Nor are the ends to which the state is supposed to be subordinate really capable of description outside the order which embodies them. This is certainly true of the liberal end of freedom. Naturally, one's neighbors may interfere with one, to a greater or lesser extent, but until we are given some concrete description of the social and political arrangement, it is impossible to say whether this interference is desirable. The interference' proper to a rural community in Zululand is greater than anything experienced in a Soviet city. Yet it would be sadly misguided to call it a loss of freedom, when subjection to this kind of interference is precisely what it is to be a Zulu. And as soon as there is interference, there is a form of rule, and therefore a state, however loosely constituted. Without some move in this direction, towards constituted power, a person is neither free nor unfree, but lives like the nomads of the anarchistic commune, in a perpetual hallucination of freedom that can be translated only into solipsistic acts. ${ }^{104}$

Seen in this light, Mr. Bork's views on privacy take on a new coherence. He has gone from describing Griswold as "a salutary demonstration of the Court's ability to protect fundamental human values"105 to describing it as an "unprincipled" and "utterly specious" decision, a "constitutional time-bomb." Mr. Bork's new belief that society must legislate moral values if it is not to dissolve social bonds (p. 249) is clearly related to this about-face over privacy. The Burkean Mr. Bork believes there are compelling reasons for government interference in decisions the liberal would regard as "personal." For the liberal, the fact that these decisions are not only intimate but also caught up in (relative) moral judgements is the reason the state should stay out of them. For the Burkean, on the other hand, these "moral" views are actually the basis of state and society. Given this perspective, it is hardly surprising that Mr. Bork feels that "[a] change in moral environment-in social attitudes towards sex, marriage, duties towards children and the like-may surely be felt to be as harmful as the possibility of physical violence or the absence of proportional representation of ethnic groups in the workforce" (p. 247). The issues which had seemed the farthest from the reach of permissible state interference are revealed to be constitutive of state and society. The picture has reversed itself. Roger Scruton, an English conservative, puts it particularly well:

[The] individual has become a sophisticated being, anxious for a sphere of privacy in which to seclude the eccentricities that fulfil him. His fulfillment, he thinks, is impossible without the "right of privacy" which Englishmen regard as indefeasible. But what does this right amount to when unprotected by the state? Nothing.

104. R. Scruton, The Meaning of Conservatism 47 (1984).

105. Bork, supra note 35 , at 8 . 
What is fulfillment without the values of a social order? Nothing. And whas it eccentricity without the norm against which to measure it? Nothing. This Anglo-Saxon privacy which we esteem is in fact nothing more than the public order seen from within. It is not the vacuous freedom of liberalism, but a substantial and enduring thing, whose content becomes clear only with its limits. ${ }^{106}$

Where do those limits come from? In the Burkean world they are derived from the history, customs, and traditional morality of the particular society. No wonder Mr. Bork has backed away from awarding first amendment protection to all human behavior, and prohibiting the majority's interference with what it cannot see. To the Burkean, this would give any minority carte blanche to undermine the web of meaning and morality on which the society rests. No wonder Mr. Bork now sees the plaintiff's argument in Bowers v. Hardwick, an argument indistinguishable from the one he himself made in 1968 , to be "one more sortie in our cultural war."

There is another puzzle in Mr. Bork's intellectual history which can be solved by assuming that he is moving towards a Burkean constitutional theory. Why do texts become so much clearer, history so much less ambiguous, as Mr. Bork grows older? When I first read Mr. Bork's work in chronological order, I had the distinct impression that I was moving backwards rather than forwards in time. Most people begin by seeing clarity and determinacy in their studies and then move slowly towards the recognition of conflict, indeterminacy and vagueness. When Mr. Bork first looked at original intent, he saw a "naive" attempt to wish away the complexities and indeterminacy of the historical record. Twenty years later, the same record was entirely clear to him. Considered as an intellectual progression in interpretive conclusions it seemed not impossible, but at least counter-intuitive. Yet if looked at, not as a progression of interpretive theory, but as a fundamental change in political vision, it makes more sense. From the Burkean point of view, the attractive feature of original understanding is not its specious claim to "neutrality in derivation and application of principle" but the simple fact that it attempts to solve questions of value by focusing on history and tradition. ${ }^{107}$

Tradition and history are to be valued for their own sake, not because they supply an interpretive constitutional method capable of surmount-

106. SCRUTON, supra note 104 , at $189-90$

107. Actually, there is even Burkean precedent for the specific method of original understanding, although the tone of his remarks is more instructive than their content.

Those who cultivate the memory of our revolution, and those who are attached to the constitution of this kingdom, will take good care how they are involved with persons who, under the pretext of zeal towards the Revolution and Constitution, too frequently wander from their true principles; and are ready on every occasion to depart from the firm but cautious and deliberate spirit which produced the one and presides in the other. BURKE, supra note 85, at 86 . 
ing the fact/value dichotomy. History and tradition do not allow us to climb out of the web of politics to reach some neutral ground, as the liberal would attempt to do. They instead constitute the web. For the Burkean, history and tradition are our society and there is no place outside of that society to make decisions. Just as Scruton thinks one cannot talk about the acceptable level of state intrusion without knowing whether we are talking about the traditions of Zulu or American society, a Burkean would claim that constitutional interpretation cannot and should not seek the illusory haven of a neutral method "outside of" politics, but should work from within the "prejudice," history, and tradition of this society.

There is an obvious and immediate objection to this view of Mr. Bork's work. As I have already shown, his theory rests on a very shaky historical footing. It could be objected that it is a poor representative of an ideology which purports to revere tradition. Perhaps this response misunderstands the Burkean vision because it continues to apply the assumptions of liberal rationalism. Like Mr. Bork, Burke did not have much respect for the kind of history most professional historians produce. Burke believed that individuals and societies could only exist, communicate and survive by filtering their present attitudes through the traditions, myth, and reverence which colored their history. Thus, it is hardly surprising to find that the history Burke uses to defend his ideas is an idealized, mythologized, poetic history. He even suggests that, in the rare cases when political change is necessary, one can pick and choose among the "histories" which one will use for inspiration. In Burke's mind, the failure to take this step is the great sin of pride which has tainted the French Revolution.

[Y]ou chose to act as if you had never been moulded into civil society, and had every thing to begin anew. You began ill, because you began by despising everything that belonged to you. You set up your trade without a capital. If the last generations of your country appeared without much lustre in your eyes, you might have passed them by and derived your claim from a more early race of ancestors. Under a pious predilection for those ancestors, your imaginations would have realized in them a standard of virtue and wisdom, beyond the vulgar practice of the hour: and you would have risen with the example to whose imitation you aspired. ${ }^{108}$

Bork, unlike the French Revolutionaries, follows Burke's prescription. Searching for a constitutional theory he acquires a "pious predilection" for a chosen set of ancestors and imagines "a standard of virtue and wisdom, beyond the vulgar practice of the hour." This is not history. It is

108. Id. at 122 (emphasis added). 
mythopoeia. But in Burke's world, in Giambattista Vico's ${ }^{109}$ world, and perhaps in Mr. Bork's world, mythopoeia is all there is. ${ }^{110}$

The Burkean history is a chosen history, one that suppresses those features of our "ancient liberties" which do not fit the story. One could have met Burke on his own ground by pointing out that there were also strong English ${ }^{111}$ traditions towards egalitarianism and social iconoclasm. Equally, there are moments reading Mr. Bork's version of American history where one might forget that this is a state born in revolution against a colonial power, a state infused with egalitarian as well as hierarchical traditions from its very inception. To say this is not to say that Mr. Bork's history is false by comparison with some absolutely true, egalitarian, radical republican history of the United States. The post-modernist would say that all histories are "chosen" histories, and that there is no surcease from the invention and reinvention of our past.

All this leaves us with one overriding question. I suggest that Mr. Bork is proposing a reverence towards what amounts to a comprehensive mythology predicated on the importance of stability and order. He has chosen a mythologized version of the tradition of constitutional governance, of family life, of "natural" hierarchies, and of the morality of middle America. If this is true, and if in fact the construction of mythologies is inevitable, why is Mr. Bork not more open in urging the Burkean side of his ideas? It is, of course, possible that he is unaware of that side, unaware that some of his ideas rely on the premises of liberal rationalism while others challenge those premises. The fragmentary way in which his Burkeanism appears in his book seems to indicate that this is in fact the case. In addition, Mr. Bork may have not wish to face this tendency in his thought. What happens if you are a conservative who begins to doubt the adequacy of the framework of liberal reason? If you are a progressive, then there is a certain satisfaction in breaking down the arguments which support the status quo, in showing that history and

109. G. Vico, The New SCiEnCe (M. Fisch \& T. Bergin trans. 1968).

110. This is the point where the post-modern gloss on history may be useful. For the postmodernist, there is no choice whether or not to be influenced by past history, tradition, style, and genre, but there may be a choice of which histories we choose. Where the modernist saw freedom as coming from a rejection of the forms provided by the past, the post-modernist sees freedom as existing between the opposing pulls of different traditions. The resulting collage can produce a wide range of effects. Burke deliberately played down the tradition of the Levellers and the Diggers, bowdlerized the Glorious Revolution, understated nationalist tensions, and minimized the popular attraction of liberal ideals in order to create his history of the great British traditions of government. In the hands of a less skilled thinker, his mixture of unreflective royalism, "ancient liberties," natural law moralism and utilitarian arguments for private property would have seemed ridiculous. In his hands, it acquires an internal coherency akin to the counter-intuitive logic of fairy-tales. For Burke, the test of the mixture was its success in fostering stability and order. Yet the same collage approach can be used to produce exactly the opposite result. The post-modern building, with its Victorian garrets and Italianate columns and minaret cupolas, relies on the architectural traditions of the past, and yet denies them any absolute authority by juxtaposing them in bizarre and ironic patterns.

111. To say nothing of Irish, Scottish, and Welsh. 
institutional structure are radically under-determined and thus that "the way things are" is not inexorable or inevitable. But what if you are a conservative? What if you come to realize that your strong suit is prejudice rather than reason, mythologized tradition rather than "rational progress," unquestioning affection rather than rationally-demonstrated legitimacy? Your position, I would suggest, is a difficult one. Almost, in fact, a tragic one.

[T]he conservative who has risen above the fragments of his inheritance and reflected on the desolation that has been wrought in it cannot return to an innocence which his own thinking has destroyed. He is not in the position of Sartre's existential anti-hero, forced to take responsibility for a choice which he lacks the concepts to describe. He knows what he wants, and knows the social order that would correspond to it. But in becoming self-conscious he has set himself apart from things. The reasons that he observes for sustaining the myths of his society are reasons which he cannot propagate; to propagate his reasons is to instil the world with doubt. Having struggled for articulacy, he must recommend silence. ${ }^{112}$

Perhaps this is the worm at the heart of Mr. Bork's apple. The reasons he offers for the philosophy of original understanding are poor ones. Yet to offer the reasons I have outlined here is to re-enter the skeptical world of rationalist inquiry and thus to threaten the very myths on which he would rely. Should he challenge the premises of liberal rationalism overtly? Should he offer a post-modern conservatism skeptical of the claims of reason, proud of tradition, convinced of the inevitability of myth? Or would the propagation of his reasons instil his world with doubt? It might well turn his readers away from his solutions to the problems of liberalism and towards those who criticize liberalism from the left, from faith in equality rather than in hierarchy, towards those who revere change as much as Mr. Bork reveres stability. Having struggled for articulacy, Mr. Bork chooses silence.

\section{CONCLUSION}

What is one to say about Mr. Bork's most recent argument? From the more obvious perspectives it is a notable failure. It advocates an historically-based mode of interpretation, yet the historical groundwork in it is poor and sometimes non-existent. It fails markedly to deal with the strongest theoretical and practical objections to original understanding. Its coverage of contemporary constitutional legal theory, particularly conservative legal theory, is cursory and tendentious. The jurisprudential method which forms the heart of the book contradicts Mr. Bork's own previous writing, and does not have the virtues he claims for it.

112. SCRUTON, supra note 104 , at 191. 
Poor history, bad logic, personal inconsistency and a method riddled with aporia and contradiction-it is a fairly depressing list of conclusions. The list is made more depressing when it is counterposed against the person touchingly revealed by this book, and the scholar revealed by his earlier books. It seems that at a certain point Mr. Bork decided no longer to listen to those with whom he disagreed, and decided that moral, historical and jurisprudential objections to his theories were as nothing. He became so firmly fixed in his views that he could not even wonder whether or not his ideas, too, were a contentious and political litmus test for judges, no matter how right they seemed to him. If true, this is a loss to us all, Mr. Bork included.

Some might agree with this assessment, but would lay the blame for the decline in Mr. Bork's scholarship on the trauma of the confirmation hearings. The book certainly reveals those hearings to have been a painful ordeal which, whatever the merits of the objections to Mr. Bork, had its own set of unacceptable distortions and mistakes. But in my view the process of denial started long before the confirmation hearings.

There is in all of Mr. Bork's writing an almost frantic insistence that the world must be marked out by bright lines. When insistence comes into conflict with reality, the result is denial: denial of history, of complexity, of the most cogent objections. Denial of the practice of the Supreme Court, of legal academic consensus, of public opinion. Denial of practical and theoretical difficulties and, in the end, denial of his own past work. The mechanism of denial varies. One can deny the importance of the consensus of legal academia by attributing it to a complacent class interest. "Simplification" allows Dred Scott to become a case which discredits only substantive due process and not also original understanding. The practice of the Supreme Court can be separated into heresy and correct doctrine and the former decried. The historical evidence of the Framers' intention that their understanding should not bind future generations can simply be ignored. Complexity can be denied by claiming that its recognition would start us on the slippery slope to anarchy or tyranny. Mr. Bork's own past work may be glossed over quickly. But in the end, the denial is undeniable, and it tends to undermine itself.

When a theory demands that so much of the world be sacrificed to its dictates, might it not be the theory, rather than the world, which is in error? In this essay, I tried to answer that question by going beyond the obvious contradictions and problems of The Tempting of America. When that work is set beside Mr. Bork's earlier works, it is clear that all of them have a similar theme. On one level, all of them deal with the familiar question of liberal rationalist social theory: Can we simultaneously believe that all social institutions are subject to the test of reason, and believe that values are subjective and arbitrary? If our premise is that schemes of values cannot be weighed by rational criteria, how can 
we solve the problems of liberty and order? We have seen that his attempts to address these questions have led him through a succession of conservative positions.

On the most obvious level, The Tempting of America is simply the next step in this long progression, and the weakest argument so far. The Tempting of America is unmarred by complexity or nuance. When faced by insoluble problems, the earlier Mr. Bork would try more subtle arguments. This one resorts to bluff and bluster. Yet on another level, The Tempting of America is an advance. Each of his previous positions has accepted the framework of liberal rationalism and attempted to argue within that framework. I have argued in this essay that The Tempting of America marks a break, albeit fragmentary and partial, with that tradition, and turns instead to the older ideas of Burkeanism or forward to a post-modern conservatism.

What is the value of such a turn? One possible answer was prefigured in my description of the advantages of originalism as a popular conservative theory. If conservatives want only a source of rhetoric and weighty but spurious argument, original intent and original understanding will do fairly well, either alone or in conjunction with other schools of conservative rhetoric. Consistent Burkeanism may be unnecessary. There may be rhetorical advantage to be gained from the language of the other leading conservative theories, each of which seems to fulfil the criteria for social analysis under the premises of liberalism. Each allows one to claim that her political agenda is not merely desirable, but necessary, that it is no mere preference, but an inescapable and neutral truth.

The same pattern holds true at the level of day-to-day politics. Much everyday political debate consists of a slinging match between liberals who appeal to a reified notion of "progress" and conservatives who appeal to an equally reified notion of "the free market." In such a world, an openly Burkean, a defiantly post-modern conservative philosophy would have at least novelty to recommend it. Instead of conducting all political discussion at one remove-aiming at whatever temporary shelter the opponent has constructed to shield herself from the relativity of value-one could discuss the political visions themselves. Instead of arguing about who has isolated the correct neutral principle guiding our busing decision, one could argue about whether integration would help or hurt. Instead of coating his arguments with spurious references to the true meaning of the history of the fourteenth amendment, Mr. Bork could come right out and reason from his faith in tradition, his trust of hierarchies, his unwillingness to disturb the edifice of civil society. I am not saying this is somehow the only "real" level of discussion: such a claim would be merely to re-enter the eternal minuet of liberal rationalism. But $I$ do think that it is a more interesting level of the discussion and that claim might convince where metaphysical bludgeons fail. 
In such a world Mr. Bork would be revealed for the political views which undoubtedly commend him now to his conservative friends, and which have held constant despite the apparently radical changes in his intellectual positions. What are those views? $\mathrm{He}$ is an able propagandist for a view of society which puts implicit trust in hierarchy. He has a firm belief in the "innocence" of social inequality. Partly this is because he retains enough of his libertarianism to see a deprivation of freedom only where there is an intentional nefarious act by a defined individual actor. Wards Cove ${ }^{113}$ offers Mr. Bork no particular villain, and thus he sees nothing wrong with it. ${ }^{14}$ His faith in the "innocence" of social inequality also springs from a belief that the basic processes of society operate in spontaneous good order. If everything is running normally, what could be wrong with inequality, even structural inequality? To me, living in a city where the nature of someone's life can be predicted with a fair degree of accuracy simply by knowing their race, sex, or class, these beliefs seem bizarre, crazy even. Mr. Bork's mythologised history is a constant struggle to keep pure the innocent heritage we have been left. My mythologised history is a set of dispersed and occasionally successful attempts to apply the idea of democracy to some new social institution-generally over the objections of people like Mr. Bork who have argued successfully for eons that there are no fewer than seventeen immutable reasons why the status quo is simultaneously natural, inevitable and just.

There are exceptions, however. He seems to advocate intervention to maintain a particular vision of morality and family life, without asking whether the challenges to it are deliberate or structural. Similarly, his tolerance for hierarchy disappears when he talks about the knowledge elite rather than the monied elite. His trust in tradition does not extend to the peculiarly American traditions of egalitarianism and social iconoclasm. Some of these views seem important to me. Most of them seem both wrong and pernicious. But if Mr. Bork is the herald of a postmodern conservatism, we might actually begin to talk about these issues, to reveal what conservatism has to offer apart from an unconvincing claim to the "true meaning" of history, economics, or institutional competence. Best of all, at long last, the Everyman of conservative legal theory could rest from his lifelong process of denial.

113. Wards Cove Packing Co. v. Atonio, 490 U.S. 642 (1989).

114. See Bork, Justices Did the Right Thing, L.A. Daily J., July 27, 1989, at 6. 